\title{
PRE-HISPANIC MINING ERGOLOGY OF NORTHERN CHILE: AN ARCHAEOLOGICAL PERSPECTIVE*
}

\author{
ERGOLOGÍA MINERA PREHISPÁNICA DEL NORTE DE CHILE: \\ UNA PERSPECTIVA ARQUEOLÓGICA
}

\author{
Valentina Figueroa $^{1}$, Diego Salazar ${ }^{2}$, Hernán Salinas $^{3}$, Paz Núñez-Regueiro ${ }^{4}$ and Germán Manríquez ${ }^{5}$
}

\begin{abstract}
Mines, spoils, retention walls and pads are the most common material remains of pre-Hispanic mining activity studied by archaeologists. In this paper we will focus on yet another category, the mining ergology, defined as the material artefacts associated with day to day mining activities. Mining ergology seeks to document the technological equipment of the pre-Hispanic miner, which is seldom found in archaeological contexts due to poor preservation of organic materials. The arid conditions of the Atacama desert offer unique conservation possibilities which have shown a varied mining ergology that includes hafted stone hammers bound to wooden handles with rawhide and wool, lithic hammer heads, lithic and wooden shovels, baskets and capachos (rawhide sacks). The study of these components complements our knowledge of pre-Hispanic mining technologies and increases our understanding of the organization of mining operations, the diachrony of mining activity, the variability and continuity of the material record, and therefore of mining and its development in the Andes in general.
\end{abstract}

Key words: Pre-Hispanic mining, Atacama Desert, ergology, copper.

\begin{abstract}
Minas, desmontes, muros de contención y canchas son los principales restos materiales de la actividad minera prehispánica. En este trabajo abordaremos otra categoría, complementaria a las anteriores, que definiremos como ergología minera, es decir, aquellos artefactos relacionados con el trabajo cotidiano minero. Se ha buscado documentar el equipamiento tecnológico propio del minero prehispánico, el cual rara vez se encuentra en el registro arqueológico debido a la conservación diferencial de restos orgánicos. El desierto de Atacama ofrece en este sentido condiciones únicas de preservación, a partir de las cuales ha sido posible reconocer una ergología minera variada, que incluye martillos de piedra enmangados mediante ligaduras de cuero y lana a mangos de madera, cabezales de martillos líticos, palas líticas y de madera, cestería y capachos de cuero. Este estudio complementa nuestro conocimiento sobre las tecnologías mineras prehispánicas del desierto de Atacama, permitiéndonos una mejor comprensión de la organización de las operaciones mineras, de la diacronía de las explotaciones, de la variabilidad y de las persistencias del registro artefactual, y, en consecuencia, de la minería en general y de su desarrollo en los Andes.
\end{abstract}

Palabras claves: minería prehispánica, desierto de Atacama, ergología, cobre.

Minerals and metals were one of the most important goods (Núñez 1987, 1999, 2006) traded during pre-Hispanic times in the South Central Andean Area (Browman 1984; Núñez and Dillehay 1995 [1979]; Núñez 1987). Beginning in the Late Archaic, but mainly from the Formative Period to the Inka Horizon, the production of copper-mineral beads (Rees 1999; Soto 2010), pigments (Sepúlveda and Laval 2010) and metallic objects (Letchman and MacFarlane 2005; Núñez 1987, 2006, 2012;
Figueroa, Montero et al. 2010; Figueroa 2012; Maldonado et al. 2010; Salazar, Figueroa et al. 2011) drove a significant demand for the mining of copper ores, while regional caravan trade played a crucial role in circulating these goods (Berenguer 2004; Lecoq 1987).

The earliest mining operations in South America have been recorded on the coast of Antofagasta Region in Northern Chile (Salazar, Jackson et al. 2011). Iron oxides have been extracted from this

* Artículo seleccionado del conjunto de ponencias presentadas en la Primera Reunión Internacional sobre Minería Prehispánica en América (PRIMPA), realizada en San Pedro de Atacama, Chile, diciembre 2010. Este manuscrito fue evaluado por investigadores externos y editado por Andrés Troncoso y Victoria Castro, en su calidad de editores invitados de la Revista.

1 Programa Post-doctoral, Proyecto de Investigación Asociativa Conicyt ACT96, Departamento de Geología, Facultad de Ciencias Físicas y Matemáticas, Universidad de Chile, Beauchef 850, Santiago, Chile. Valentina.Figueroa-Larre@malix.univ-paris1.fr

2 Departamento de Antropología, Facultad de Ciencias Sociales, Universidad de Chile. Av. Ignacio Carrera Pinto 1045, Piso 2, Ñunoa, Santiago, Chile.dsalazar@uchile.cl

3 MAA Consultores Ltda. salinas.williams@gmail.com

4 Musée du quai Branly, 218 rue de l’Université, 75007, Paris, France. pnr@quaibranly.fr

5 Departamento de Antropología, Facultad de Ciencias Sociales, Universidad de Chile; Programa de Genética Humana, I.C.B.M. Facultad de Medicina, Universidad de Chile. Independencia 1027, Santiago, Chile. gmanriqu@ med.uchile.cl 
site since the Early Holocene. Although copper mining appears much later in the Andes, these ores were mined much more intensely. The highlands of the Atacama Desert not only contain some of the richest copper deposits in the world, but also house significant archaeological evidence of ancient mining operations. Several mining districts (Figure 1), including El Abra, Chuquicamata and El Salvador, are known to have had mining operations as early as the Formative Period, if not before (Núñez 2006; Figueroa, Salinas et al. 2010; González and
Westfall 2008; Salazar 2002; Salazar and Salinas 2008; Salazar, Salinas et al. 2010). Others, such as Collahuasi and probably San Bartolo, contain Late Intermediate mines that were still in use during Inka times (Aldunate et al. 2008; Lynch and Núñez 1994). When the Spaniards arrived in what is today Northern Chile, they found a copper mining tradition nearly 5000 years old, most notably in the Atacama Region (Núñez et al. 2005).

Despite the critical value of copper production over the last 5000 years of prehistory in Northern

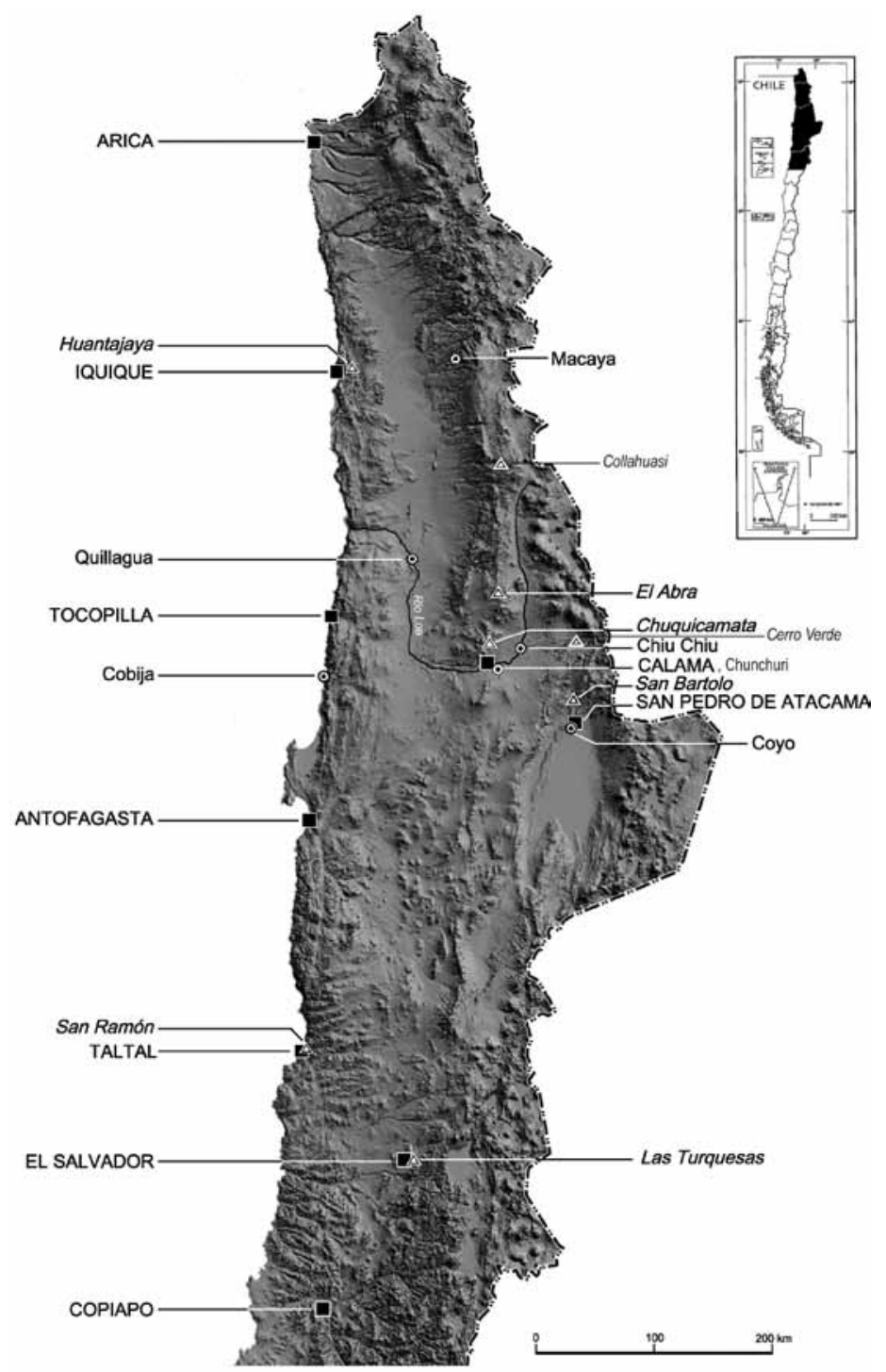

Figure 1. Map of Northern Chile's mining districts and localities mentioned in the text.

Mapa de los distritos mineros y de las localidades del Norte de Chile mencionados en el texto. 
Chile and the South Central Andes in general, mining archaeology began fairly recently in these territories, as it did in the rest of South America (Salazar 2003-2004). This is mainly due to the lack of direct evidence of prehistoric mining, which was often destroyed by colonial and modern mining operations. Studies of mining ethnohistory (Bakewell 1989; Berthelot 1978; Bouysse-Cassagne 2005, 2008; Platt et al. 2006; Cruz 2009) and the anthropology of mining (Absi 2003; Godoy 1985; Nash 1979; Salazar-Soler 2002) have been more prosperous for systematic research in the Andes.

However, not all archaeological evidence was destroyed by later mining activity; a few prehistoric copper mines have been recorded and studied in the Andes (e.g. Westfall and González 2010;
Iribarren 1972-73; Núñez 1999; Salazar 2002, 2008; Salinas and Salazar 2008; Salazar and Salinas 2008; Salazar, Salinas et al. 2010). These studies, however, have focused mainly on describing the sites themselves and their archaeological contexts, while the technology that enabled their operation has not been lent the same attention (but see Salinas 2007; Salinas et al. 2010).

In this paper we attempt to complement our understanding of prehistoric mining in the Andes through an archaeological examination of the mining ergology in use in Northern Chile before the Spanish arrival. "Mining ergology" refers herein to the corpus of everyday technical instruments and artefacts used by pre-Hispanic miners (Figure 2). Within this corpus we can distinguish between the

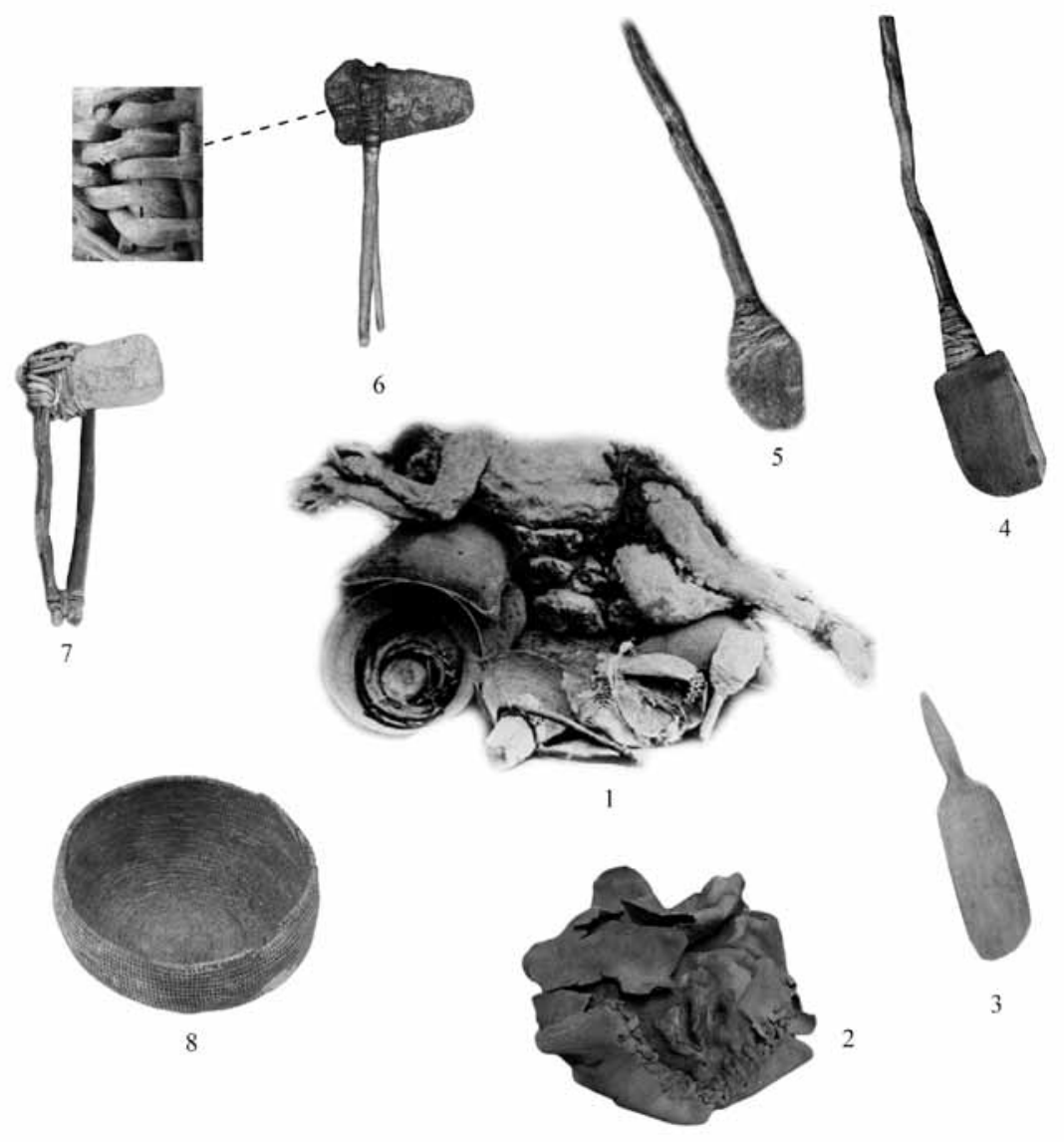

Figure 2. Prehispanic mining ergology from the Atacama Desert. 1. Copper Man (Chuquicamata), (AMNH); 2. Capacho (Taltal), (Museo Augusto Capdeville de Taltal); 3. Shovel (Calama), (Musée du quai Branly); 4-5. Shovel (Chiu-Chiu), (Museo de América); 6. Hafted stone hammer (Chiu-Chiu), (Museum of World Cultures, Goteborg); 7. Hafted stone hammer (Chuquicamata), (Musée du quai Branly); 8. Basketry (Chuquicamata) (Musée du quai Branly).

Ergología minera prehispánica del desierto de Atacama.1. Hombre de Cobre (Chuquicamata), (AMNH); 2. Capacho (Taltal), (Museo Augusto Capdeville de Taltal); 3. Pala (Calama), (Musée du quai Branly); 4-5. Palas (Chiu-Chiu), (Museo de América); 6. Martillo enmangado (Chiu-Chiu) (Museum of World Cultures, Goteborg); 7. Martillo enmangado (Chuquicamata) (Musée du quai Branly); 8. Cestería (Chuquicamata) (Musée du quai Branly). 
Mining set, which corresponds to formal shaped tools adapted to the functional requirements of mining activity, and the Personal Effects of agents directly involved in mining. Following Shepperd (1980), the Mining set can be further classified into Working Tools and Transport Materials. Since these items have rarely been found all together in archaeological contexts, we will analyze evidence from different sources-including museum collections, archaeological and bioanthropological remains from excavations, and ethnohistorical information- in order to propose a model (Figure 3) of the pre-Hispanic mining ergology of Northern Chile to complement the study of prehistoric mining sites themselves, which in turn are part of larger production systems (Salazar and Salinas 2008) ${ }^{1}$. We believe this model may be of interest beyond Northern Chile, as it will help to conceptualize the variability of instruments and practices associated with mining operations in other areas of the world as well.

\section{Indigenous Mining Ergology in Ethnohistorical Documents}

Research on prehistoric mining has been especially fruitful over the past 15 years in Northern Chile, owing in large measure to environmental impact assessments (contract archaeology) in mining districts. Today, the identification and contextualization of mining landscapes and their associated artefacts has contributed to the extensive record that exists for Northern Chile, and especially the Atacama Region, which has enabled the reconstruction of a more comprehensive characterization of copper mining in the past (Aldunate et al. 2008; Corrales 2003; Westfall and González 2010; Figueroa, Salinas et al. 2010; Núñez 1999, 2006; Núñez et al. 2003; Salazar 2002, 2003 2004, 2008; Salazar and Salinas 2008; Salazar et al. 2007; Salazar, Salinas et al. 2010; Salinas 2007; Salinas and Salazar 2008; Salinas et al. 2010).

However, although much has been discovered about the archaeology of mining in Northern Chile and the Andes in general, there is still a lot to learn about the artefacts associated with pre-Hispanic mining activities. Thus, from an archaeological perspective, understanding the technological variability or areas of expertise of mining workers still present challenges (Salinas et al. 2010). In this respect, ethnohistorical data provides complementary information that is valuable for understanding pre-Hispanic mining ergology, even despite the fact that colonial sources were more interested in metallurgical processes than in mining itself (Gil Montero 2012).

Early testimonies such as those of Pedro Sancho de la Hoz (1938 [1534]) referring to cervid antlers and rawhide capachos are vital for reconstructing the traditional indigenous mining artefact assemblage as these artefacts have rarely been found in archaeological contexts: 'Mining is done with deer antlers and the ore and other material is taken from the mines in sacks sewn from leather or sheepskin' (Sancho de la Hoz 1938 [1534], in Petersen 2010: 41).

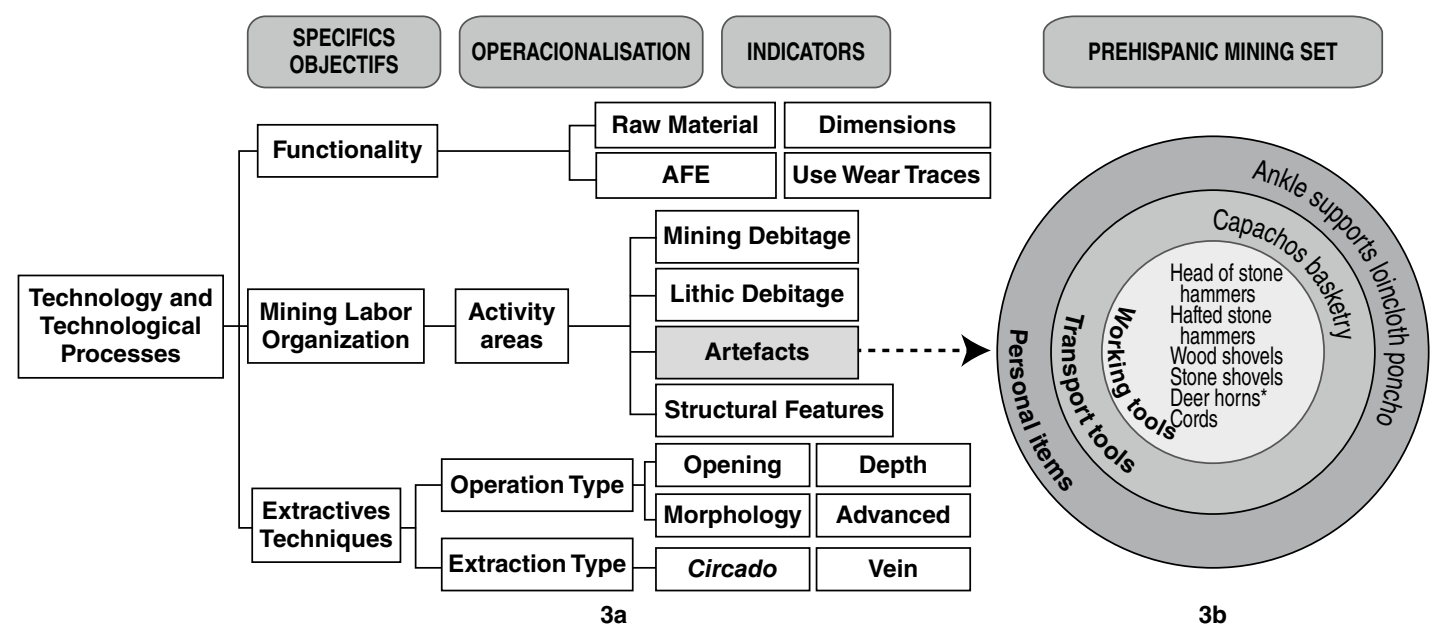

Figure 3. (3a) Mining production model following Salazar and Salinas (2008); (3b) Mining set according to archaeological evidence. (3a) Modelo de la producción minera según Salazar y Salinas (2008); (3b) Conjunto minero acorde con las evidencias arqueológicas. 
Additionally, in 1590 Father José de Acosta described other important aspects of early colonial indigenous mining ergology (cited by Gil Montero 2012):

Trabajan con velas siempre los que labran, repartiendo el trabajo de suerte que unos labran de día y descansan de noche y otros al revés les suceden. El metal es duro comúnmente y sácanlo a golpe de barreta quebrantándole que es quebrar un pedernal. Después lo suben a cuestas por unas escaleras hechizas de tres ramales de cuero de vaca retorcido como gruesas maromas, y de un ramal a otro puestos palos como escalones, de manera que pueden subir un hombre y bajar otro juntamente. Tienen estas escalas de largo diez estados, $\mathrm{y}$ al fin de ellas está otra escala del mismo largo, que comienza de un releje o apoyo, donde hay hechos de madera unos descansos a manera de andamios, porque son muchas las escalas que se suben. Saca un hombre carga de dos arrobas atada la manta a los pechos y el metal que va en ella, a las espaldas; suben de tres en tres. El delantero lleva una vela atada al dedo pulgar, para que vean ${ }^{2}$.

However, given the fact that major transformations in indigenous economies and technologies occurred from the beginning of the Spanish colonial administration (Varón 1978; Bakewell 1989; Gil Montero 2012), caution should be taken with these sources when reconstructing the pre-Hispanic mining ergology of Northern Chile. Furthermore, the bulk of $16^{\text {th }}$ and $17^{\text {th }}$ century mining descriptions refer to Potosí, Porco, Chuquiabo, Carabaya or Huancavélica, which cannot be compared to preHispanic mining sites in Northern Chile, either in terms of the organization and scale of production or the ores extracted.

Nevertheless, we agree with Mendoza (1983:35), who stated in reference to García de Llanos ([1609] 1983) mining dictionary that, although 'it has been largely conceived and intended for the silver ores of Potosí, it can be applied to other metals and other geographical areas through analogy'. This dictionary is especially relevant because of its early date, as the introduction of gunpowder in Andean mining operations in the $17^{\text {th }}$ Century dramatically changed the indigenous technologies thereafter (Gil Montero 2012). The dictionary therefore contains valuable information about pre-Hispanic mining technologies that were implicit in indigenous concepts alluding to the different phases and categories of the mining process (Mendoza 1983:35). Indeed, one notable aspect of the above mentioned dictionary is the quantity of indigenous terms that it contains: 160 of the 258 terms defined are native, and deal with all the phases of the mining process. Figure 4 offers a comprehensive list of mining sets in the Potosí context according to the dictionary compiled by García de Llanos (1983 [1609]) as an example, regarding working artefacts the dictionary states:

\section{Comba comes from the word cumpa, which in Quechua means big hammer, and the Indians gave this name to very round, ball-like stones of every size that they use for their tasks. Thus in the old working areas of Oruro and other mines, many have been found from that period (...), and here people are said to combear with this instrument, which is the same as hitting (García de Llanos 1983 [1609]:54) ${ }^{3}$. [Translate by the authors].}

Complementary information can be found in the Quechua dictionary of the Spanish priest González Holguín, who mentions the use of the word jutcuna to refer to a sort of drill (barreno), the circana to a

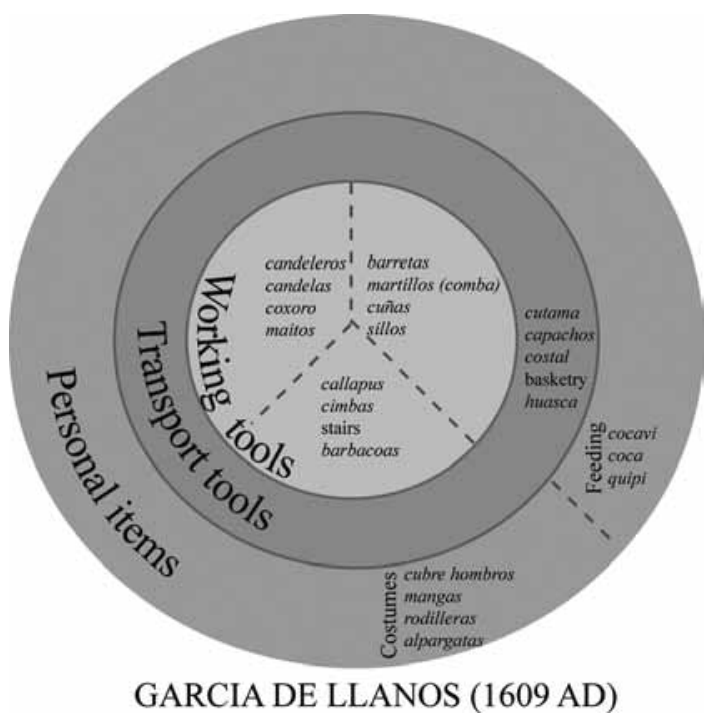

Figure 4. Mining set from the Early Colony according to García de Llanos (1983 [1609]).

Conjunto minero de la Colonia Temprana según García de Llanos (1983 [1609]). 
chisel and the cotama to the bag used for transporting the ore out of the mine (Money 2004).

In addition to the instruments themselves, García de Llanos (1983 [1609]) describes different workers-cateadores, ayciris, pirquiris, apiris, pailliris, carnereros, candelacamayoc-with very specific tasks within the mine, shedding a light on the level of specialisation of mining work (Table 1). In this regard, it is interesting to compare the theoretical stages of the mining productive process-from extraction to selection, through the different phases of crushing and milling (Salazar 2003-2004, Salinas and Salazar 2008), with the different mining activities and specialists described by García de Llanos (Figure 5).

All of these dictionaries, as well as Father Bertonio's on the Aymara language (see Money 2004) provide information on the different minerals and mineral deposits developed by pre-Hispanic miners and the techniques they used for extracting ores. Nevertheless, this information is of secondary importance to this article.

\section{Mining Ergology of Northern Chile}

Northern Chile is one of the richest areas of the Andes for pre-Hispanic mining ergology. Artefacts made of perishable materials and even the human remains of miners have been preserved here by

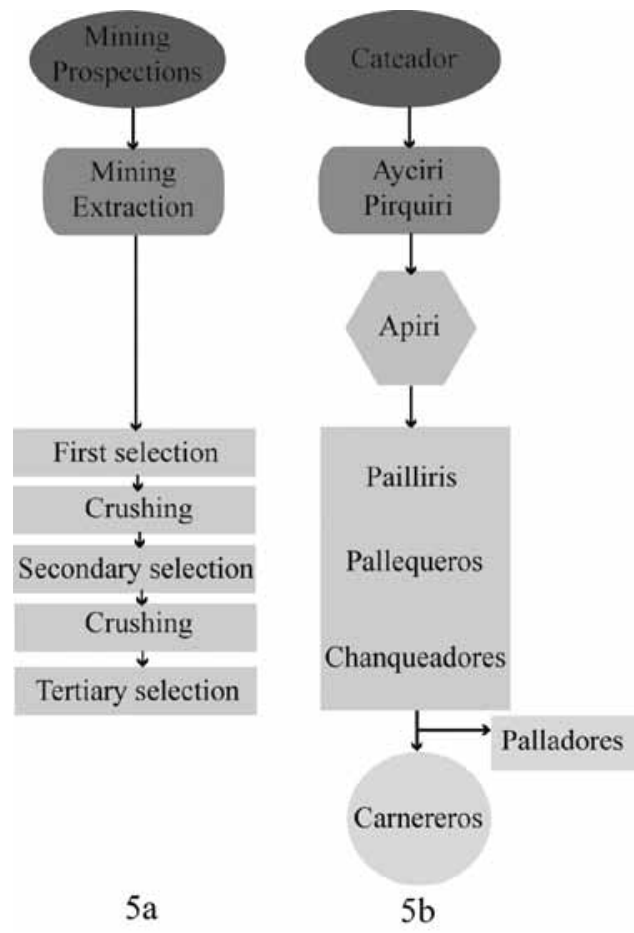

Figure 5. (5a) Schematic model of the mining chaîne opératoire as defined by Salazar (2003-2004) and Salinas and Salazar (2008) compared to García de Llanos (1983 [1609]) description of miners (5b). (5a) Modelo esquemático de la cadena operativa minera definida por Salazar (2003-2004) y Salinas y Salazar (2008) comparado con la descripción de los oficios mineros realizada por García de Llanos (1983 [1609]) (5b).

Table 1. Mining occupations described by García de Llanos (1983 [1609]).

Oficios mineros descritos por García de Llanos (1983 [1609]).

\begin{tabular}{|c|c|c|c|}
\hline Occupation & Task & Tool & Qualities \\
\hline Cateador & Seeking and discovering mineral veins & Hammer & $\begin{array}{l}\text { "Buscón" (seeker), } \\
\text { surveyor }\end{array}$ \\
\hline $\begin{array}{l}\text { Barretero, Ayciri, } \\
\text { llamador }\end{array}$ & Cutting the mineral & $\begin{array}{l}\text { Pole } \\
\text { Wedge } \\
\text { Hammer }\end{array}$ & Strong and skilled \\
\hline Pirquiris & Putting supports within the mines & HammerC & $\begin{array}{l}\text { Dextrous, highly } \\
\text { estimated, and rightly so }\end{array}$ \\
\hline Apiri / sacador & $\begin{array}{l}\text { Taking out and loading the mineral extracted } \\
\text { from the mine }\end{array}$ & $\begin{array}{l}\text { Capacho } \\
\text { Sack }\end{array}$ & $\begin{array}{l}\text { Indians less able to work } \\
\text { or beginners }\end{array}$ \\
\hline Pailliri & $\begin{array}{l}\text { Cleaning the mineral in the canchas, separating } \\
\text { poor quality material and disposing of it }\end{array}$ & Sledgehammer & Youth and elders \\
\hline Pallaqueros & Fine separation of high-grade ores from the rock & Sledgehammer Crusher & Skilled, young \\
\hline Chanqueadores & $\begin{array}{l}\text { "Chanquean" el material "pallaqueado" } \\
\text { (Crushing the finely separated material) }\end{array}$ & Sledgehammer & Skilled, young \\
\hline Palladores & Re-detaching & Sledgehammer & Uruquillas \\
\hline Candelacamayos & $\begin{array}{l}\text { Making candles for the labours in the depths of } \\
\text { the pit }\end{array}$ & $\begin{array}{l}\text { Candles } \\
\text { Wax }\end{array}$ & \\
\hline Carnerero, arriero & $\begin{array}{l}\text { Transporting the mineral from the mine to the } \\
\text { working areas }\end{array}$ & $\begin{array}{l}\text { Sack } \\
\text { Animals of burden }\end{array}$ & \\
\hline
\end{tabular}


the hyperarid conditions in the Atacama Desert. Even so, only a small portion of this evidence has been studied and/or reported in publications. We have identified evidence of pre-Hispanic mining ergology from Northern Chile housed in museums both in Chile and abroad, and have complemented this information with the results of our own research on prehistoric copper mines in the Atacama Region. The results presented herein therefore represent the most thorough review of pre-Hispanic mining ergology ever published.
The most significant evidence gathered to date comes from the main mining districts of Northern Chile such as Chuquicamata, San José del Abra, Salar de Atacama, San Bartolo, El Salvador and Huantajaya (a silver mine). We will review that evidence below.

The general inventory of mining objects from Northern Chile that is considered in this paper includes approximately 650 archaeological objects related to mining production and seven human bodies (Table 2). Most of the archaeological objects

Table 2. Archaeological objects and seven individuals related to mining production from Northern Chile (*Many authors have mentioned the same object)

Objetos arqueológicos y siete individuos relacionados con la producción minera del Norte de Chile (*Varios autores hicieron mención del mismo objeto).

\begin{tabular}{|c|c|c|c|c|c|c|c|c|c|c|c|}
\hline $\begin{array}{l}\text { Finding information } \\
\text { Context }\end{array}$ & Locality & Reference & Mummy & $\begin{array}{l}\text { Rawhide } \\
\text { bag }\end{array}$ & Shovel & $\begin{array}{l}\text { Head } \\
\text { stone } \\
\text { hammer }\end{array}$ & $\begin{array}{l}\text { Hafted } \\
\text { stone } \\
\text { hammer }\end{array}$ & $\begin{array}{l}\text { handle/ } \\
\text { rawhide } \\
\text { cords }\end{array}$ & Handle & Sticks & Basketry \\
\hline Huantajaya mine & Huantajaya & $\begin{array}{l}\text { Brown and } \\
\text { Craig } 1994\end{array}$ & 2 & 1 & & & 1 & & & & \\
\hline Copper Man & Chuquicamata & Morgan 1899 & 1 & 1 & 1 & & 1 & & & & 2 \\
\hline Chile Exploration & Chuquicamata & Sullivan 1921/ & & & & & & & & & \\
\hline Company 1 & & Mead 1921 & 1 & $1^{*}$ & $2 *$ & & $4^{*}$ & & $2 *$ & & \\
\hline Chile Exploration & Chuquicamata & Camus 2003 & & & & & & & & & \\
\hline Company & & & 1 & & $1^{*}$ & & $3^{*}$ & & & & \\
\hline $\begin{array}{l}\text { AMNH } 1912 \text { (US } \\
\text { National Museum) }\end{array}$ & Chuquicamata & Bird 1979 & & & & & & & & & \\
\hline $\begin{array}{l}\text { National Museum) } \\
\text { AMNH } 1914 \\
\text { (US National + }\end{array}$ & Chuquicamata & Bird 1979 & & $1^{*}$ & $4^{*}$ & & $4^{*}$ & & & $5^{*}$ & 4* \\
\hline Guggenheim) & & & & & $4 *$ & 17 & $17^{*}$ & & & $9^{*}$ & $2 *$ \\
\hline Anaconda Company & Chuquicamata & $\begin{array}{l}\text { Craddock et al. } \\
2003\end{array}$ & & & & & 1 & & & & \\
\hline $\begin{array}{l}\text { Sénéchal de la Grange } \\
\text { (1902) }\end{array}$ & Chuquicamata & Chervin 1902 & 1 & 1 & & 4 & & 1 & & & 1 \\
\hline $\begin{array}{l}\text { Mission Scientifique } \\
\text { Française (G. Courty }\end{array}$ & Chuquicamata & Boman 1908 & & & & & & & & & \\
\hline 1903) & & & & & & & 2 & & & & \\
\hline Ricardo Latcham & Chuquicamata & Latcham 1938 & & & & & 1 & & & & \\
\hline Thompson Collection & Chuquicamata & Salinas 2007 & & 1 & & & 3 & & & & \\
\hline Peabody Musem & Chuquicamata & $\begin{array}{l}\text { Archive Peabody } \\
\text { Museum }\end{array}$ & & & & 1 & & 1 & & & \\
\hline Alfred Métraux & Chiu-Chiu & Archives Goterborg & & & & & & & & & \\
\hline (Goteborg) & & Museum & & & & & 1 & & & & \\
\hline Aureliano Oyarzún & Chiu-Chiu & $\begin{array}{l}\text { Archives Museo } \\
\text { Histórico Nacional } \\
\text { (Santiago) }\end{array}$ & & & & & 2 & & 1 & & \\
\hline Museo Geológico de & Chiu-Chiu & Archives Museo & & & & & & & & & \\
\hline Chiu-Chiu & & Chiu-Chiu & & & & & 1 & & & & \\
\hline El Abra District & El Abra & Salinas 2007 & & & 2 & 503 & & & & & \\
\hline Rodulfo Philippi & San Bartolo & Philippi 1860 & & & 1 & & 1 & & & & \\
\hline Ricardo Latcham & San Bartolo & Latcham 1938 & & & & & 1 & & & & \\
\hline Ricardo Latcham & Quillagua & Latcham 1938 & & & & & 1 & & & & \\
\hline Llagostera and Costa & Coyo 3 & $\begin{array}{l}\text { Llagostera and } \\
\text { Costa } 1994\end{array}$ & & & & 8 & & & & & \\
\hline Museo Augusto & Taltal & $\begin{array}{l}\text { notes } \\
\text { Archive Museum }\end{array}$ & & & & 40 & 1 & & & & \\
\hline Capdeville (Taltal) & & Taltal & & 2 & & & & & & & \\
\hline El Salvador & Las Turquesas & Kuzmanic and & & & & & & & & & \\
\hline (Atacama) & & Sanhueza 1984 & 1 & & & & & & & & \\
\hline
\end{tabular}


described have been analyzed in museum collections and/or field campaigns, while some of the organic artefacts (i.e. wooden) have been dated and studied for taxonomic identification. This complementary analysis was performed mainly on shovels and hammers that were selected according to criteria such as context, reliable chronological associations, type of object and state of conservation.

The sections below present a review of the main finds by mining district:

\section{Chuquicamata}

Between the first foreign mining works and the large-scale operations of US firms like the Chile Exploration Company and the Anaconda Company, at least three mummies of miners and several associated tools such as hammers and hafted shovels were found in this world-renowned district: the so-called Copper Man and two other bodies were discovered by the Chile Exploration Company in Chuquicamata (Figure 6). In 1903, the Mission Scientifique Française en Amérique du Sud, led by Georges de Créqui-Montfort and Eugène Sénéchal de la Grange, explored the mining districts of the Atacama Desert, finding several artefacts related to mining and metallurgical production, particularly in the area of Chuquicamata (Boman 1908; Chervin 1902; Léjeal 1904), as well as a fourth body, bringing the total number of mummies of miners from Chuquicamata to four. All four were found in mineshafts that were in use in pre-Hispanic times, and three of them have been positively associated with their mining ergology.

\section{US Companies}

The Copper Man mummy and his mining ergology were discovered in 1899 in the Restauradora mine of Chuquicamata and have been exhaustively described and commented on in numerous publications (Bird 1977-1978, 1979; Craddock et al. 2003; Figueroa, Salinas et al. 2010; Mead 1921; Medina 1901, 1919); Núñez 1999, 2012; Petersen 2010; Philippi 1901; Stoellner 2011; Sullivan 1921; Weisgerber 2006).

According to the picture taken in 1899 , the artefacts found alongside Copper Man included a hammer, a shovel, basketry and a capacho. The miner also was found with personal items such as braids, ankle supports and a loincloth. According to

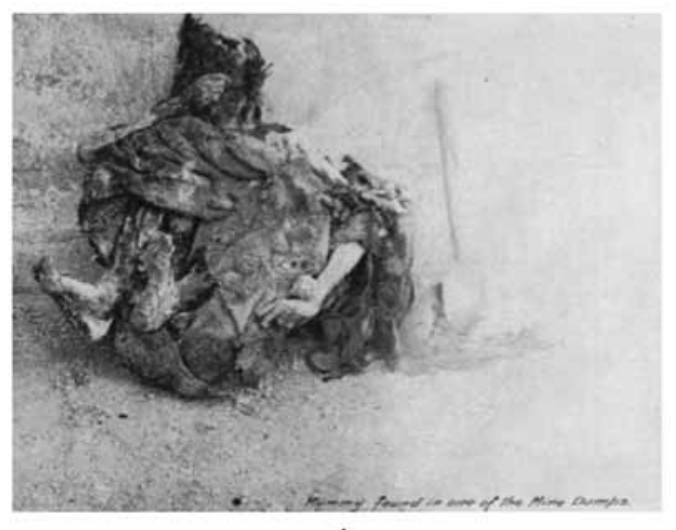

1

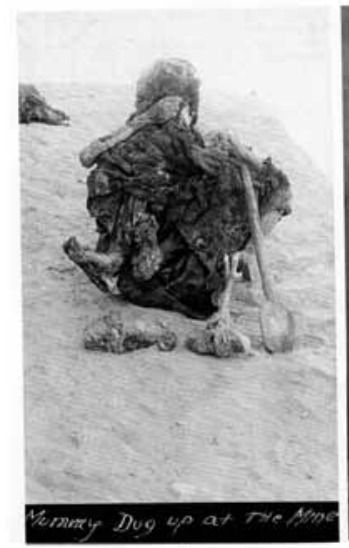

2

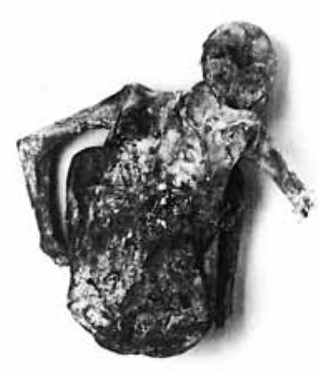

4

Figure 6. Four photographs of two pre-Hispanic mummies from Chuquicamata (6.1. Sutulov 1975; 6.2. Camus 2003; 6.3. Camus 2003; 6.4. Weisberger 2006).

Cuatro fotografías de dos momias prehispánicas de Chuquicamata (6.1. Sutulov 1975; 6.2. Camus 2003; 6.3. Camus 2003; 6.4. Weisberger 2006).

Bird (1979:112) the American Museum of Natural History (AMNH) only acquired some of the objects found with the miner and other hafted stone hammers from Chuquicamata in 1912. In 1914, new objects were entered into the Museum's records, these ones donated by the Guggenheim brothers ${ }^{4}$. 
Because the archaeological context and cultural affiliation of the numerous (ca. 50) and diverse array of objects found in the district of Chuquicamata remain unclear, the importance of the radiocarbon dates published by Bird (1979) cannot be underestimated, as they revealed for the first time the antiquity of mining operations in the Atacama region (Table 3). In regard to dating, while human tissue fragments and alpaca wool have been dated to the $6^{\text {th }}$ century $\mathrm{AD}$, the hammerstone handle found was dated 500 years later (Bird 1979:132; Craddock et al. 2003:62; Salazar, Figueroa et al. 2011:143). These divergent dates may be explained by the fact that the artefacts associated with the find were obtained separately by the U.S. National Museum (Washington D.C.) and only entered the American Museum of Natural History (AMNH) collection in 1912 as part of a set of hafted hammers from Chuquicamata, in which hammerstones and handles may have been mismatched (Bird 1979:112).

Mead (1921) refers to a second miner mummy acquired by the AMNH in 1921 as a donation from the Guggenheim brothers. The body of the miner was exhumed from the Restauradora mine in Chuquicamata in 1914 while 'a cross-cut was being cleared out in their mine' (Mead 1921:453). According to Mead (1921:353) "A poncho, several stone hammers, and wooden shovels, or scrapers, were found with it; but the workmen who dug it out were not interested in these things and they were not preserved" . However, Sullivan's report (1921) describes two hafted shovels, one with a lithic blade -that appears to be the Copper Man's shovel- and the other with a wooden blade, which may have belonged to this second mummy.

Four photographs of the body were taken (Figure 6). The first is captioned "Mummy dug up at the mine" (Figure 6.1) and shows an individual in flexed position covered by a textile (Sutulov 1975:4). The right hand is resting above the head while the left is bent in a ' $v$ ' shape. The left clavicle is visible, and the feet are flexed so that the soles are almost vertical. It is not possible to describe the hair in detail. A one-piece wooden shovel with a long handle can be observed in the background.

The second photo (Figure 6.2) is entitled "Mummy found in one of the mine dumps" (Camus 2003) and shows the same individual in the former picture from another angle. The body and artefacts appear to have been organised and cleaned expressly for this new shot, which suggests it was taken after the first. On the left side of the body are the same wooden shovel observed in Figure 6.1 and three different hammers not shown in the previous photo.

There is a third picture that bears the inscription 'Chile exploration Co. Mine Department. Accession

Table 3. Radiocarbon dates of artefacts from archaeological mining contexts of the Atacama Desert.

Fechas radiocarbónicas de artefactos provenientes de contextos arqueológicos mineros del desierto de Atacama.

\begin{tabular}{|c|c|c|c|c|c|c|c|c|}
\hline Locality & Sample Material & Reference & Lab Code & ${ }^{14} \mathrm{C}$ date & $\begin{array}{l}\text { Calibrated } \\
\text { date (BP) }\end{array}$ & $\begin{array}{l}\text { Range } \\
\text { (BP) }\end{array}$ & $\begin{array}{l}\text { Calibrated } \\
\text { date }(\mathrm{AD})\end{array}$ & $\begin{array}{l}\text { Range } \\
\text { (AD) }\end{array}$ \\
\hline Chuquicamata & Human tissue & Bird 1979 & LJ3947 & $1400 \pm 40 \mathrm{BP}$ & 1274 & $(1178-1329)$ & 676 & $(621-772)$ \\
\hline Chuquicamata & $\begin{array}{l}\text { Llama or alpaca wool } \\
\text { cloth (treated with acetone) }\end{array}$ & Bird 1979 & LJ3948 & $1650 \pm 130 \mathrm{BP}$ & 1503 & $(1288-1813)$ & 447 & $(137-662)$ \\
\hline Chuquicamata & $\begin{array}{l}\text { Llama or alpaca wool } \\
\text { cloth (untreated) }\end{array}$ & Bird 1979 & LJ3949 & $1350 \pm 80 \mathrm{BP}$ & 1208 & (1009-1347) & 742 & $(603-941)$ \\
\hline Chuquicamata & $\begin{array}{l}\text { Wood shavings from } \\
\text { the hammer handle }\end{array}$ & Bird 1979 & LJ3950 & $840 \pm 150 \mathrm{BP}$ & 742 & $(516-1042)$ & 1208 & $(908-1434)$ \\
\hline Chuquicamata & $\begin{array}{l}\text { Wood shavings from } \\
\text { the hammer handle }\end{array}$ & $\begin{array}{l}\text { Craddock } \\
\text { et al. } 2003\end{array}$ & AA18886 & $1804 \pm 48 \mathrm{BP}$ & 1659 & $(1546-1812)$ & 291 & (138-404) \\
\hline Chuquicamata & $\begin{array}{l}\text { Wood shavings from } \\
\text { the hammer handle }\end{array}$ & this paper & POZ 37208 & $1505 \pm 30 \mathrm{BP}$ & 1340 & (1297-1394) & 610 & $(556-653)$ \\
\hline Chuquicamata & $\begin{array}{l}\text { Wood shavings from } \\
\text { the hammer handle }\end{array}$ & this paper & POZ 37209 & $890 \pm 30 \mathrm{BP}$ & 753 & $(683-895)$ & 1197 & $(1055-1267)$ \\
\hline Chuquicamata & $\begin{array}{l}\text { Wood shavings from } \\
\text { the hammer handle }\end{array}$ & this paper & POZ-37207 & $895 \pm 30 \mathrm{BP}$ & 757 & $(685-897)$ & 1193 & $(1053-1265)$ \\
\hline $\begin{array}{l}\text { El Abra } \\
(\mathrm{AB}-83)\end{array}$ & $\begin{array}{l}\text { Wood shavings from } \\
\text { the shovel blade }\end{array}$ & $\begin{array}{l}\text { Salazar, Salinas } \\
\text { et al. } 2010\end{array}$ & Beta 217771 & $910 \pm 50 \mathrm{BP}$ & 777 & $(682-907)$ & 1173 & $(1043-1268)$ \\
\hline $\begin{array}{l}\text { El Abra } \\
(\mathrm{AB}-22 / 39)\end{array}$ & $\begin{array}{l}\text { Wood shavings from } \\
\text { the shovel blade }\end{array}$ & $\begin{array}{l}\text { Salazar et al. } \\
\text { this volume }\end{array}$ & Beta 287255 & $830 \pm 40 \mathrm{BP}$ & 708 & $(664-767)$ & 1242 & $(1183-1286)$ \\
\hline
\end{tabular}


$N^{o} 20$. Indian mummies taken from underground workings. July 16, 1920' (Camus 2003) (Figure 6.3). Two individuals were photographed. On the left is a body in poor state of preservation and to the right is a flexed body. The individual on the left is the same one seen in Figures 6.1 and 6.2. The position of the arms, legs and clavicle are the same in all three pictures, the only difference being that in Figure 6.3 the individual appears with no clothing, as he also does in Figure 6.4 (Weisberger 2006). There are no records of the individual on the right (Figure 6.3) at the AMNH.

As mentioned above, the second mummy from Chuquicamata was found in 1914 and acquired by the AMNH around 1921. Picture 6.3 bears the date July 1920, and in that photo the mummy appears without artefacts. It is likely that the mummies' artefacts were taken to the US in 1914, the same year of the finding and 7 years before the mummy itself. Indeed, there was significant traffic of mining instruments at the time, making the reconstruction of contexts vital. In 1986, for example, W.B. Wray bought a miner's hammer at the offices of the Anaconda Copper Mining Co. (1915-1971) in New York. The hammer had a handwritten tag attached that read 'Stone hammer from old workings at extreme South end Bench D-2', and another one glued to the hammer with the same information (Craddock et al. 2003:57) (Figure 7.1). Craddock et al. (2003) performed an exhaustive study of this artefact. His studies on the handle demonstrated that it was made of Prosopis chilensis (algarrobo) wood, and the ligatures were lama or alpaca rawhide. Its radiocarbon date of 138-404 cal AD (1804 \pm 48 BP) (Craddock et al. 2003:62) makes this the oldest mining instrument found in Chile to date (Table 3 ). The authors attempted to situate the hammer from 'Bench D-2' both temporally and geographically in one of the mining sites, commenting that 'We believe that the hammer which is the subject of this report may have been found in 1915 when actual mining commenced, or perhaps within a few years after 1915' (Craddock et al. 2003:58-59). Another hammer ( $\mathrm{n}^{\circ}$ 44-4-30/4256) associated with a handle $\left(\mathrm{n}^{\circ}\right.$ 44-4-30/4256.1) is housed in the Peabody Museum, with the only reference indicating that the object came from Chuquicamata (Figure 7.2).

\section{Mission Scientifique Française en Amérique du Sud}

In 1903 the Mission Scientifique Française (MSF) led by Georges de Créqui-Monfort and Sénéchal de la Grange explored Northern Chile, Argentina, Peru and Bolivia. Two members of the Mission, Eugène Sénéchal de la Grange and Georges Courty, surveyed the Chuquicamata district. The year before, Sénéchal de la Grange had travelled to Chuquicamata and found the mummy of a miner

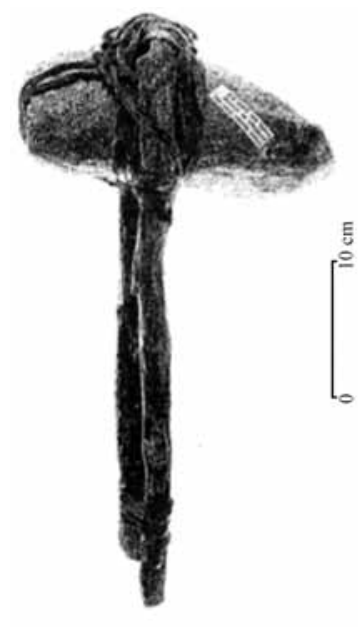

1

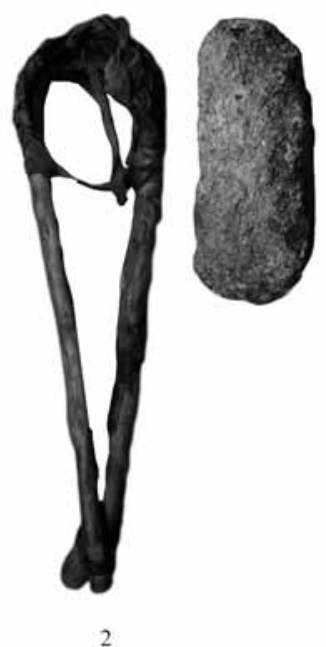

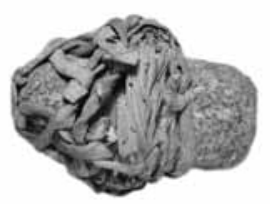

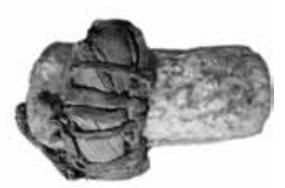

5

Figure 7. Hafted stone hammers from Chuquicamata: (7.1) Anaconda Company (Craddock et al. 2003); (7.2). Peabody Museum; (7.3-5). Thompson Collection (Salinas 2007).

Martillos líticos enmangados procedentes de Chuquicamata: (7.1) Anaconda Company (Craddock et al. 2003); (7.2). Peabody Museum; (7.3-5). Thompson Collection (Salinas 2007). 
covered by a textile, with assembled braids and different artefacts unique to the tool-set of a miner. According to Chervin's (1902: 704) description, the body presents evidence of suffering a violent death: "The woman worked in the mines of Chuquicamata; her head was smashed by a mine collapse of date unknown" 6 . The body is associated with numerous objects of the mining ergology (hafted stone hammers, lithic hammer heads, basketry, a rawhide capacho). The current location of this mummy is unknown ${ }^{7}$ and of its mining set only the whereabouts of a wooden handle and its ligatures, three lithic hammerheads and one basket are known: they are currently housed in the Musée du quai Branly in Paris $^{8}$ (Figure 8.1-4).

Léjeal (1904) and Boman (1908) later referred to this same find, confirming the existence of the mummified miner. In an essay on the 'Exposition de la Mission Française de l'Amérique du Sud au Palais du Trocadéro', Léjeal (1904:326) refers to the mummy and the work implements, stating: the mummy, now in its final sleep amongst the collections of Mr. de Créqui is that of a miner surrounded by its specialised instruments. The work in the mines was a usual occupation of all those antique peoples and the beautiful set of axes collected in Salinas Grandes in Argentina confirms an exploitation from the oldest of times [translated by the authors].

Boman (1908:757) also describes the objects that accompanied the female miner mummy, pointing out that:

Mr. Sénéchal de la Grange brought from Chuquicamata the mummified cadaver of a woman in 1902, described by Dr. A. Chervin (98, p. 705). Close to her was a lithic hafted-hammer (...) a rawhide bag containing two stones and finally the same type of basketry we have described for

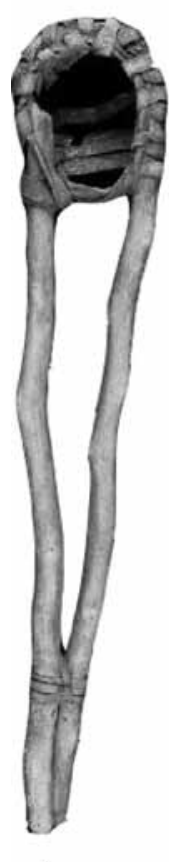

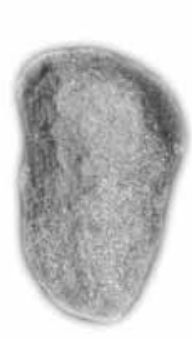

2

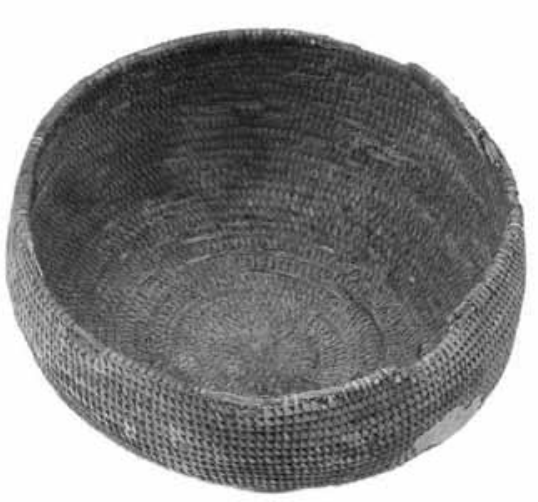

4

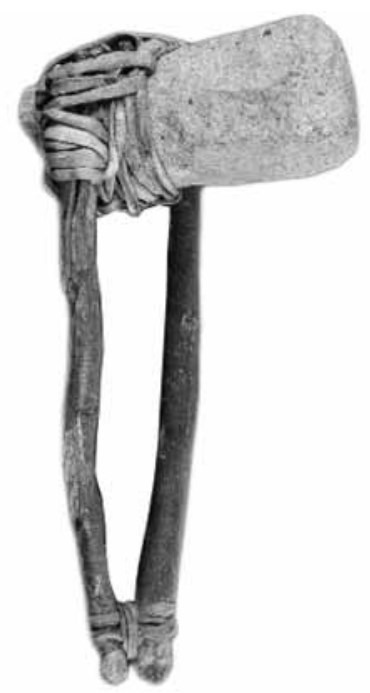

5

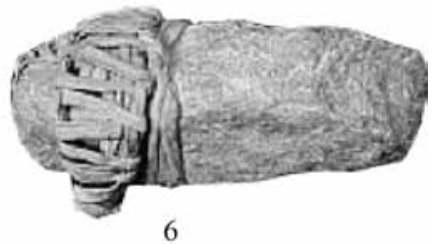

Figure 8. Hafted stone hammers and basket from Chuquicamata. 8.1-4. Mining set associated with the body of a miner found by Sénéchal de la Grange in 1902 (Musée du quai Branly); 8.5-6. Two hafted stone hammers found by Courty in 1903 (Musée du quai Branly).

Martillos líticos enmangados y cestería procedente de Chuquicamata. 8.1-4. Conjunto minero asociado con el cuerpo de un minero encontrado por Sénéchal de la Grange en 1902 (Musée du quai Branly); 8.5-6. Dos martillos líticos enmangados encontrados por Courty en 1903 (Musée du quai Branly). 
Calama. This woman may have worked in the Chuquicamata mines where her head might have been smashed by a collapse [translated by the authors].

Two other hafted-hammers were collected during the 1903 MSF expedition by Georges Courty (Figure 8.5-6). Courty found a heavy stone hammer with its handle and a lithic shovel fragment inside a llampera ${ }^{9}$ (Boman 1908; Courty $1907)^{10}$. A second hammer appears without a handle, but wood fragments can be observed within the rawhide netting. We recorded these objects and obtained microsamples for radiocarbon dating (AMS), and the results for both pieces associated with the miner mummy are coherent with prior evidence of copper mining in the Chuquicamata District. The hammer associated with the miner (Figure 8.1) was dated to 556$653 \mathrm{cal}$ AD $(1505 \pm 30 \mathrm{BP})$, contemporary with Copper Man. The other two correspond to the Late Intermediate Period, with dates between 1055-1267 cal AD (890 $\pm 30 \mathrm{BP})$ and 1053-1265 cal AD $(895 \pm 30 \mathrm{BP})(\text { Figure } 8.5-6 \text {, Table } 3)^{11}$.

\section{Other findings from Chuquicamata}

Other mining artefacts have also been mentioned for the Chuquicamata District. Latcham (1938) mentions the presence of a lithic hafted-hammer, while Salinas (2007) documented three hammers from the Thompson Collection, likely also from Chuquicamata (Figure 7.3-5). The evidence from site CHU-2 also needs to be added. Located 1,500 $\mathrm{m}$ from the current Chuquicamata site, CHU-2 has been interpreted as a mining camp dated ca. 780-1,020 cal AD, and was a place from which miners such as Copper Man may have accessed their work areas (Núñez et al. 2003). Although no complete pieces were reported, the finds included possible lithic shovel blades, a few threads and fleece interpreted as the remains of sacks and/or work clothes, Prosopis wood fragments that could have been haftings of work instruments, and small unhafted lithic hammerstones (Núñez et al. 2003).

\section{San José del Abra}

The San José del Abra mining district, located around $50 \mathrm{~km}$ northeast of Chuquicamata, was being worked by local indigenous communities from the Late Formative Period onwards, and perhaps even earlier. The first studies of this area were conducted by Núñez and focused specifically on the main Inka mines and a sample of more than 300 lithic hammerstones (Núñez 1999). Beginning in 1999, investigations led by Salazar and colleagues have continued research on the Inka mines and on other prehistoric copper and turquoise mines ranging from the Late Formative (ca. 200 AD) to the Inka periods (1,400-1,550 AD) (Salazar 2002, 2008; Salazar and Salinas 2008; Salinas and Salazar 2008). Regarding mining artefacts, two categories have been found in situ: lithic hammerstones and wooden shovels. No other artefacts related to mining work have been found, with the exception of cactus needles, which could have been used in the weaving or sewing of capachos (Salazar 2008:64).

The most recurrent of the two elements of the mining set found at El Abra are lithic hammerstones; although none of the handles remained due to the poor conditions, many of them display notches for hafting. Using different analytical techniques (petrography, use-wear analyses and morphometrics) more than 500 hammerstones from 3 different mines located in San José del Abra have been studied (Salinas 2007; Salinas et al. 2010). A functional approach to the study of these artefacts was developed (Salinas et al. 2010) as a step up from preliminary typologies based on the morphology of the hammerstones (Craddock 1990; Espérou 1992; Núñez 1999; Pickin 1990; Thorburn 1990; Timberlake 1990). This approach considered three main variables: the morphology of the "functional active edge", the lithic raw material and the dimensions of the hammers (i.e., size, volume and weight). Use-wear traces were considered complementary data as an experimental approach has not yet been developed. The results of these analyses showed an interesting variability in the hammerstone ensemble, including the occurrence of both hafted and unhafted hammerstones. Two main groups of raw materials were identified in both types of hammers, namely andesites and granodiorites. Variability was also detected in the shape of the active edge of the instruments and their overall dimensions. Furthermore, hammerstone variability was seen to change over time as mining activities became more specialized and intensive (Salinas 2007; Salinas et al. 2010; Salazar and Salinas 2008). These are interesting results inasmuch as they demonstrate that the typological category of "mining hammerstone" needs to be further divided into subcategories of specimens. Indeed, a more precise typology of lithic mining instruments 
could help us to understand the organization of production in prehistoric times and how it changed over time, both topics which cannot be addressed from etnohistorical data or from a morphological classification of the hammerstones.

The second type of pre-Hispanic mining artefact from San José del Abra are the shovels. According to Latcham (1938), there are two types of shovels in the Atacama region: wooden and slabs. Among the wooden shovels three kinds of blades can be identified: elongated, pseudo-oval and quadrangular. It is interesting to note that, unlike what is usually assumed, Salazar (2008) has reported that lithic shovels so typical of this region are virtually absent from all mining contexts in San José del Abra. However, two wooden shovels were found in excavations within this district. The first has an elongated blade and short haft made from Prosopis chilensis (algarrobo) wood and has been dated between 1043-1268 cal AD $(910 \pm 50 \mathrm{BP})$ (Figure 9.1). The second has a quadrangular blade, though it is fractured. Histological analysis shows that it also is made of $P$. chilensis (algarrobo) and its radiocarbon date (1183-1286 cal AD (830 \pm 40 BP)) is very similar to the former one (Figure 9.2). The typology of both mining shovels is identical to that of pre-Hispanic agricultural shovels found in the oases of Chiu-Chiu and Calama, thus supporting a link between these instruments, as other authors have previously suggested (Bird 1979; Latcham 1938; Núñez 1999).

\section{Other mining districts in Northern Chile}

\section{Chiu-Chiu}

Four hafted hammers and a haft without its hammerstone have been found in the oasis of ChiuChiu. The museum at Chiu-Chiu houses a distinct double-hafted piece (Figure 10.1). This is another interesting specimen as it displays the variability of mining hammers (single and double hafted), a distinction that has yet to be interpreted functionally and/or technologically. A second specimen is housed in the Museum of World Cultures in Goteborg and was probably donated by Alfred Métraux in 1941 while he was director of the Instituto de Etnología of the Universidad Nacional de Tucumán, in Argentina (Figure 10.2). Lastly, two hammers and one handle with the tag Chiu-Chiu are located at the Museo Histórico Nacional in Santiago, Chile and may have been part of the Aureliano Oyarzún Collection.

\section{Huantajaya}

It is said that in Tarapacá there was a vein of precious white silver that belonged to the Sun, which the indigenous miners did not want the Spaniards to discover because 'their conjurers told them they would all die and their sown fields would dry if they discovered it' (Pizarro [1571] 1963 [XXXX]: 222 in Bouysse-Cassagne 2005). Huantajaya was an Inka mine renowned for its native silver veins that

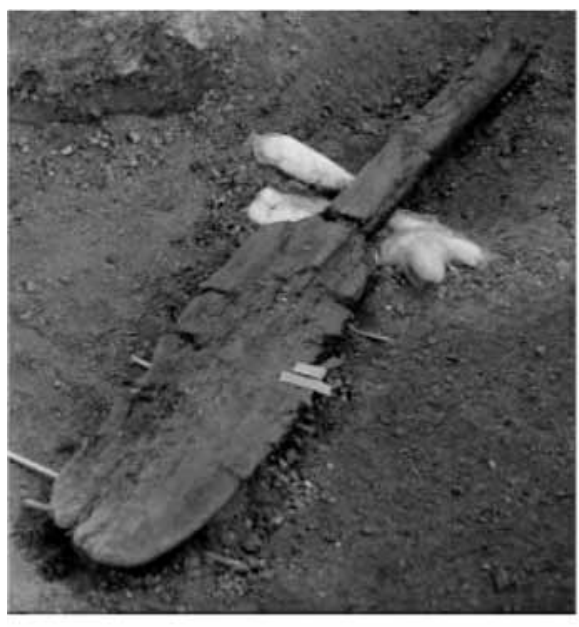

1

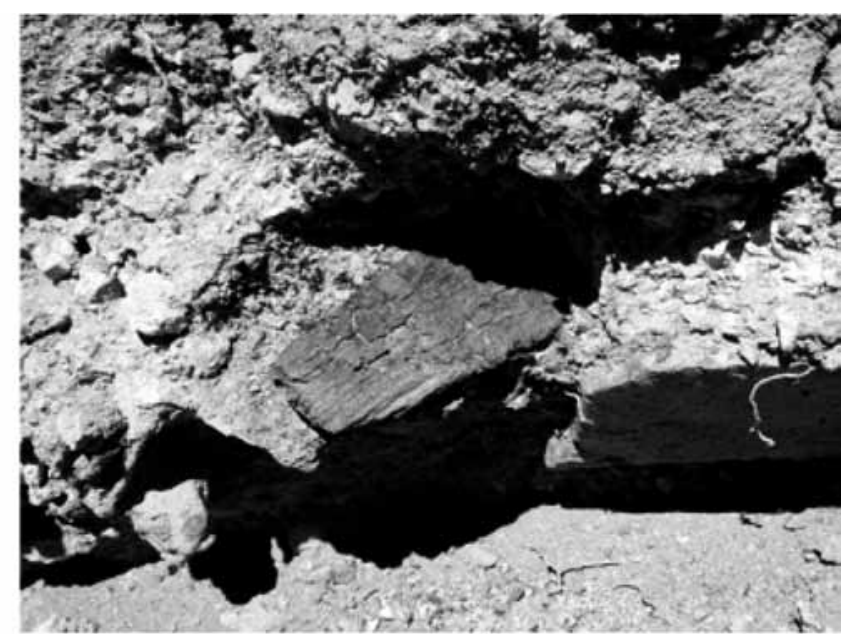

Figure 9. Wooden shovels from San José del Abra. (9.1) AB-83; (9.2) AB-39.

Palas de madera de San José del Abra. (9.1) AB-83; (9.2) AB-39. 


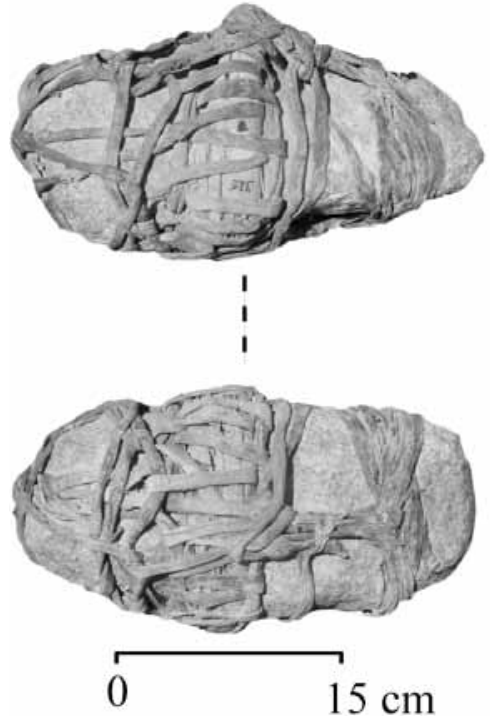

1

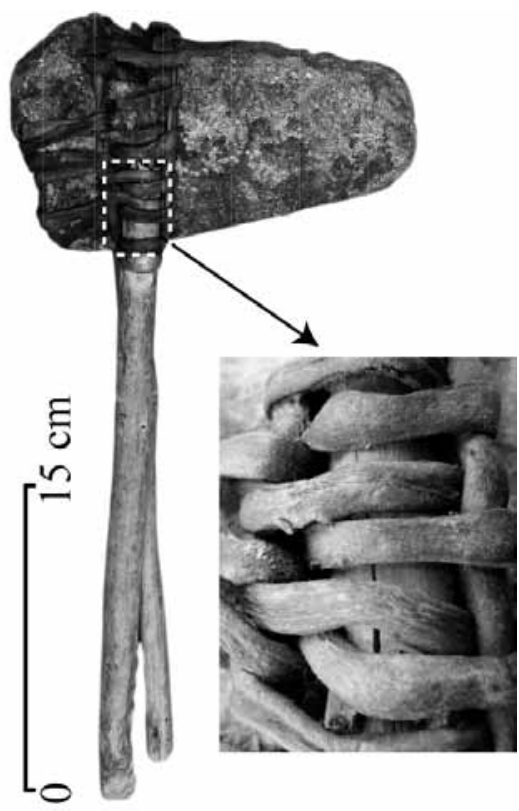

2

Figure 10. Hafted stone hammers from Chiu-Chiu: (10.1) Museo Chiu-Chiu; (10.2) Collected by Alfred Métraux (Museum of World Cultures, Goteborg).

Martillos líticos enmangados de Chiu-Chiu: (10.1) Museo Geológico de Chiu-Chiu; (10.2) Recolectado por Alfred Métraux (Museum of World Cultures, Goteborg).

was worked in the Early Colonial period (Berthelot 1978; Bouysse-Cassagne 2005; Gavira 2005; Platt et al. 2006). Although the treasured silver mine of Huantajaya was well known -it was even associated with the capacocha child- sacrifice ceremony at Cerro Esmeralda (Checura 1977)- there is little direct evidence of pre-Hispanic or Early Colonial mining operations in the area. The Huantajaya mine was reactivated in the late $18^{\text {th }}$ century, which in turn triggered the opening of several mining contexts in the Pampa del Tamarugal, where the main resources to process the ores, namely water and firewood, were to be found. However, mining activity had declined by the early years of the $19^{\text {th }}$ century (Hidalgo and Castillo 2004, Gavira 2005), and today the only visible evidence at the site are the $18^{\text {th }}$ - and $19^{\text {th }}$-century mineshafts and trenches. Nonetheless, Brown and Craig (1994) describe the bodies of two pre-Hispanic miners that were found in an ancient mineshaft along with a hammer and a rawhide capacho. The hammer and its broken haft are currently housed at the Museo Chileno de Arte Precolombino; the bodies, however, were not preserved.

\section{Atacama Salt Flat}

Le Paige mentions 40 mining hammers found in 33 tombs associated with materials from the Middle Period at the Coyo Oriente site (Le Paige 1972-73; Llagostera 2004; Salazar, Figueroa et al. 2011; Núñez 1999). In fact, in his field notes about the cemetery Le Paige draws one of the hafted hammers (Figure 11), adding:

The cemetery of Coyo Oriental brings us new things: $1 /$ tomb with stone "mallethammer", sometimes copper caliche, but painted green, with a central circular canal where the bended haft ensembles (See plate). The only cemetery in the area with this work equipment. Maybe because there is a copper vein in the foothills? [translated by the authors].

On the other hand, eight mining hammers have been reported from site Coyo-3 (Costa and Llagostera 1994). There have been no systematic studies of these objects up to now. 


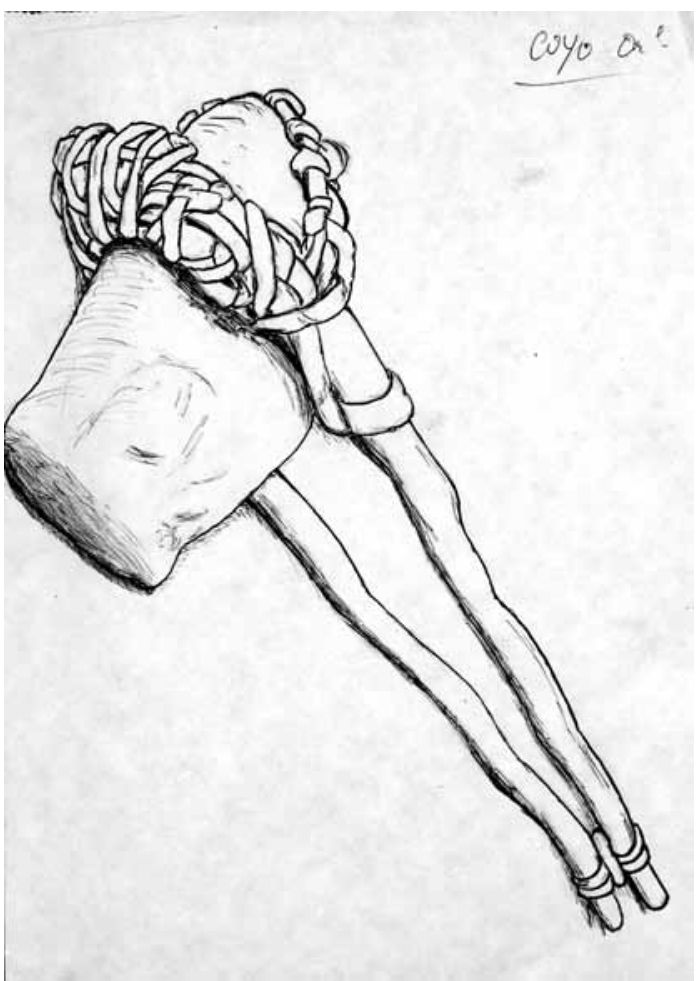

Figure 11. Hafted stone hammer from Coyo Oriente (unpublished notes from R.P. G. Le Paige, Museo Arqueológico R.P. G. Le Paige).

Martillo lítico enmangado de Coyo Oriente (notas inéditas de R.P. G. Le Paige, Museo Arqueológico R.P. G. Le Paige).

\section{San Bartolo}

As mentioned above, Philippi (1860) refers to the discovery of a hammer and a wooden shovel in the San Bartolo district (Aldunate et al. 2008; Núñez et al. 2003), and Latcham (1938: 118, 124) later mentions that the Museo Histórico Nacional housed a hammer from San Bartolo, which was probably the same item described by Philippi.

\section{El Salvador}

Initially explored by Iribarren (1972-73), Las Turquesas mine and the nearby cemetery of the same name have been recently reassessed. Las Turquesas is a turquoise mine with interior galleries associated with a mineral crushing and processing area, with occupations presumably from the Formative (500 BC) to the Inka Period (1400 AD) (González and Westfall 2008). The mine contains three pits, a gallery, and structures such as a stairway carved out of the rock, a wood-and-stone slab bridge and an adit for light and ventilation. According to former Codelco miners, vessels, capachos, ropes, cords and rawhide sandals could be seen inside the mine, items that have since disappeared (Westfall and González 2010) even though Iribarren (1972-73) was able to record some of them. Recently, González and Westfall (2008) analysed and reinterpreted a funeral bundle from Las Turquesas cemetery (Late Intermediate Period) that was first described by Kuzmanic and Sanhueza (1984), also from the El Salvador mining district. The evidence of multiple trauma revealed by radiographic analyses and the presence of turquoise in small pouches, necklaces and other objects associated with the body point to the "Atacameño caravanning and mining orientation of the individual' (González and Westfall 2008:56).

\section{A Model For Pre-Hispanic Mining Ergology}

The exceptional conditions for preservation in many parts of the Atacama Desert have enabled an understanding of pre-Hispanic mining ergology that is unlikely to be possible in other parts of the world. Our review of the evidence available for Northern Chile shows a complex ensemble of artefacts. An ideal model of the mining set would include hafted hammers and unhafted hammerstones, as well as wood and lithic shovels as the main working tools. Deer horns have also been mentioned as mining implements in Peruvian mines (Bray 1971; Weisberger 2006; Vetter 2008) but have not yet been reported in Northern Chile. Transport Materials would be capachos, basketry, cords and textile bags. Finally, the Personal Effects of pre-Hispanic miners include ankle supports, loincloths, ponchos and hair braids. Sandals are also mentioned for Las Turquesas (Westfall and González 2010), but no further evidence is available today.

As most of the evidence available comes from the Atacama region, in the central part of the Atacama Desert, we are not yet in a position to understand the geographical and/or cultural variability of preHispanic mining ergology of Northern Chile as a whole. However, since the hafted hammers, shovels and mummified bodies from the Atacama Region have been radiocarbon dated, we can propose a preliminary chronology for this ergology, at least for this territory. The oldest evidence of mining objects known in the region to date goes back to the Formative Period, and the most recent dates to 
the Late Intermediate Period (PIT) (Table 3), even though these objects were in use during Inca Period as well. Of course, these pre-Hispanic periods provide further information from known mines, crushing areas, spoils and mining campsites, which complement the data presented here from the mining ergology (Núñez et al. 2003; Salazar 2008; Salazar, Salinas et al. 2010).

More interesting, however, is the fact that our data shows that each category of artefact in the mining ergology of the prehistoric miners of the Atacama Region exhibits a significant degree of variability in the raw materials used and the shape, size and technology of the specimens. Further research is needed in order to identify more precisely the different subcategories of work tools, transport materials and personal effects of the ancient miners, as well as their temporal and geographic distribution in Northern Chile. For example, available data demonstrates that rocks used as hammerstones may include andesites/basalts and granites/granodiorites (Salinas 2007); that they may be secured to the handle by a single or double haft; that hides and/ or plant and animal fibres may be used for hafting; that the rock itself may be collected from riverbeds and hafted directly or it may be prepared through quarrying and carving, and so on.

We propose that this variability should not be only of typological and/or chronological concern, but should be approached from a functional perspective as well. Our hypothesis is that the internal differences of the mining set and its inter-site variability is mainly the result of raw material availability, the different natural determinants (i.e. host rock, ore type, local topography) on instrument performance, and the different tasks in the chain of production (i.e. extraction, primary or secondary crushing, etc.) (see Salazar 2003-2004; Salinas 2007; Salinas and Salazar 2008). It remains unclear whether this variability is temporally dependent as well, but most likely chronological differences will be more evident in the personal effects of the miners.

Within the mining set, only some instruments were specially designed for ore extraction, processing and transport, while others such as shovels, textile bags and baskets were used in other productive contexts as well. While the latter probably arrived at mining production sites as finished artefacts and were repaired locally, specialized mining instruments such as hammerstones and possibly capachos would have been produced locally. Thus the social and economic organization of mining production would have had to include accessing the raw materials required and transforming them into finished artefacts. This is especially true for large-scale operations, given that it has been experimentally demonstrated that the life-use of hammerstones is short (Craddock 1990; Craddock et al. 2003). Any understanding of these pre-Hispanic mining operations therefore needs to take into account the ways in which raw materials were accessed and processed, which may well mean looking beyond the mining archaeological context itself.

Lastly, the bioanthropology of pre-Hispanic miners such as the so-called Copper Man offers an important and complementary potential for research. One promising avenue of research involves the incorporation of bioindicators normally used in studies of present-day populations into archaeological analyses; these could include the evaluation of the biomechanical and toxicological effects of mining activity on the individual, or the study of musculoskeletal stress markers (see Mejía et al. this volume, Sarikaya et al. 2006, 2007; van der Merwe et al. 2010, Grattan et al. 2002 and 2005, Munizaga et al. 1975, among others). Considering that the effects of mining activity on the body will depend on the minerals extracted, the features of the mine, the intensity of the activity and the technology available, among other variables, the results of the above cited studies should be interpreted with caution and cannot be generalized until obtaining new evidences from detailed analysis of prehistoric miner bodies.

Therefore, complementary research that focuses on mining sites and features, the variability of the mining ergology and the bioanthropology of ancient miners will put us in a better position to achieve a truly holistic understanding of pre-Hispanic mining in the Andes in general and in Northern Chile in particular (sensu Shimada 1994). Our paper is a step in that direction.

\section{Final Remarks}

The longstanding pre-Hispanic mining tradition, which extended from the Archaic to the Inka Period, coupled with the privileged conservation conditions in the Atacama Desert strongly support the continuation of research devoted to indigenous mining in Northern Chile, its historical transformations and its relation to the environmental and sociocultural 
context in which it took place. Such research should be interdisciplinary and should combine the study of mining sites, the mining ergology and the bioanthropology of the miners themselves. As stated above, Northern Chile is one of the most privileged places in the world for such studies.

The aim of this study was to contribute to this long-term research objective by focusing on what we have defined as mining ergology, which includes the mining set of artefacts (working tools and transport materials), as well as the personal effects of the agents involved in the production process. We have sought to summarise the information available from different museums in Chile and abroad, from early scientific missions and traveller's notes, from isolated finds, photographic archives, programmed archaeological excavations and archaeological impact assessments, and from ethnohistorical sources. The ideal model of pre-Hispanic mining ergology that emerges from these sources probably cannot be generalized beyond the Atacama Region, but it does show that different tool types were in use at least from the Formative Period onwards, and that they exhibit significant variability in the properties most related to their function in a mining context: raw material, shape, size and technology. Only a few of these artefacts were designed exclusively to be used in mining contexts. But even those that were initially designed for other productive activities (mainly agriculture and to a lesser extent forestry) became useful tools to carry out mining tasks. Future research may well demonstrate that even shovels, textile bags or other instruments originally developed in economic contexts distinct from mining were transformed in order to fit the requirements of copper extraction and processing, giving birth to new types of instruments that complement the vast repertoire of traditional Andean technologies.

For now, we believe that our preliminary proposal of a mining ergology model makes finds such as Copper Man -hitherto the leitmotif of pre-Hispanic mining-a more integrated element in pre-Hispanic mining systems of Northern Chile, rather than an anecdotic find.

Acknowledgements: Our research was partially supported by the Programa de Investigación Asociativa Anillos en Ciencia y Tecnología (Conicyt), ACT No 096 (www.cienciaymemoria. cl), Proyecto FONDECYT 1100905 and Proyecto Arqueológico El Abra. Our sincerest gratitude goes to our colleagues who participated in fieldwork campaigns and laboratory analysis. We are especially grateful to the museums that allowed us to study their collections. In Chile: the Museo Augusto Capdeville de Taltal, Museo Arqueológico R.P. G. Le Paige, Museo Histórico Nacional and Museo Geológico de Chiu-Chiu. Abroad: thanks to Adriana Muñoz and Farzaneh Bagherzaneh (Museum of World Cultures, Goteborg), Christophe Moulherat (Musée du quai Branly), and Catherine Lavier (CNRS, UMR 171). Thanks also to Helena Horta for drawing our attention to Oyarzún's hammers and to Nicolas Lira, Fernanda Kalazich, Joan Donaghey, Héctor Orellana and three anonymous reviewers for their insightful comments.

\section{References Cited}

Absi, P. 2003. Les Ministres du Diable. Le Travail et ses Représentations dans les mines de Potosí. Editions L'Harmattan, Paris.

Aldunate, C., V. Castro and V. Varela 2008. San Bartolo y Cobija: Testimonios de un modo de vida minero en las tierras altas y la costa de Atacama. Estudios Atacameños 35:97-118.

Bakewell, P. 1989. Mineros en la Montaña Roja. El Trabajo de los Indios en Potosí, 1545-1650. Alianza Editorial, Madrid.

Berenguer, J. 2004. Caravanas, Interacción y Cambio Cultural en el Desierto de Atacama. Ediciones Sirawi, Santiago.

Berthelot J. 1978. L'exploitation des métaux précieux au temps des Incas. Annales. Économies, Sociétés, Civilisations 33 (5-6):948-966.

Bird, J. 1977-78. El Hombre de Cobre, un minero prehistórico del Norte de Chile y sus herramientas. Boletín del Museo Arqueológico de La Serena 16:77-106.
- - - 1979. The "Copper man": a prehistoric miner and his tools from northern Chile. In Precolumbian Metallurgy of South America, edited by E. Benson, pp. 105-132. Dumbarton Oaks Research Library and Collection, Washington.

Boman, E. 1908. Antiquités de la Région Andine et du Désert d'Atacama. Imprimerie Nationale, Paris.

Bouysse-Cassagne, T. 2005. Las minas del centro-sur andino, los cultos prehispánicos y los cultos cristianos. Bulletin de l'Institut Français d'Etudes Andines 34 (3):443-462.

- - - 2008. Minas del sol, del Inka, y de la gente. Potosí en el contexto de la minería prehispana. In Minas y Metalurgias en los Andes del Sur, entre la Época Prehispánica y el Siglo XVII, edited by P. Cruz and J. Vacher, pp. 278-301. Instituto Francés de Estudios Andinos et Institut de Recherche pour le Développement (IRD), Sucre. 
Bray, W. 1971. Ancient American Metal-Smiths. Proceedings of the Royal Anthropological Institute of Great Britain and Ireland 1971:25-43.

Browman, D. 1984. Tiwanaku: development of interzonal trade and economic expansion in the Altiplano. In Social and Economic Organization in the Prehispanic Andes, edited by D. Browman, pp. 117-142. BAR International Series 1994, England.

Brown, K. and A. Craig 1994. Silver Mining at Huantajaya, Viceroyalty of Peru. In In Quest of Mineral Wealth: Aboriginal and Colonial Mining and Metallurgy in Spanish America, edited by A. Craig y R. West, pp. 303-327. Baton Rouge, LA, Department of Geography and Anthropology, Louisiana.

Camus, F. 2003. Geología de los Sistemas Porfíricos en los Andes de Chile. Sernageomin, Santiago.

Courty, G. 1907. Explorations géologiques dans l'Amérique du Sud, suivi de tableaux météorologiques. In Mission Scientifique G. de Créqui Montfort et E. Sénéchal de la Grange, Vol. VIII. Imprimerie Nationale, Paris.

Checura, J. 1977 Funebria incaica en el Cerro Esmeralda (Iquique, I Región). Estudios Atacameños 5:127-144.

Chervin A. 1902. Crânes, pointes de flèches en silex et instruments de pêche provenant de la baie d'Antofagasta. Momies des hautsplateaux de la Bolivie. Bulletins de la Société d'anthropologie de Paris 5 (3):700-708.

Corrales P. 2003. Actividades minero-metalúrgicas: Un modelo de aproximación. Informe Final de Práctica Profesional, Departamento de Antropología, Universidad de Chile, Santiago.

Costa, M.A. and A. Llagostera 1994. Coyo 3: Momentos finales del Período Medio en San Pedro de Atacama. Estudios Atacameños 11:73-107.

Craddock, B.R. 1990. The experimental hafting of stone mining hammers. In Early mining in the British Isles, edited by P. Crew and S. Crew, p. 58. Plas Tan \& Bwlch Snowdonia National Park Study Center, London.

Craddock, B.R., C.R. Cartwright, P.T. Craddock and W.B. Wray 2003. Hafted stone mining hammer from Chuquicamata, Chile. In Mining and Metal Production Through the Ages, edited by P. Craddock y J. Lang, pp. 52-68. British Museum Press, London.

Cruz, P. 2009. Huacas olvidadas y cerros santos: Apuntes metodológicos sobre la cartografía sagrada en los Andes del sur de Bolivia. Estudios Atacameños 38:55-74.

Espérou J.L., P. Roques and P. Ambert 1992. L'outillage des mineurs préhistoriques de Cabrières: Les Broyeurs. Archéologie en Languedoc 15:67-76.

Figueroa, V. Métallurgie Préhispanique des Sociétés du Littoral Pacifique dans le Chili Septentrional (850 apr. J.-C.-1540 apr. J.C.). Thèse de Doctorat, Université de Paris 1 Panthéon-Sorbonne.

Figueroa, V., I. Montero and S. Rovira 2010. Estudio Tecnológico de objetos procedentes de Cerro Turquesa (San José del Abra, II Region). Actas del XVII Congreso Nacional de Arqueología, Tomo 2, pp. 1135-1147. Ediciones Kultrún, Valdivia.

Figueroa, V., H. Salinas, D. Salazar, G. Manríquez G and P. Núñez-Regueiro 2010. Prehispanic hammerstones from the Atacama Desert (Antofagasta region, North of Chile). In Mining in European History and his Impact on Environment and
Human Societies. Proceedings for the 1st Mining in European History-Conference of the SFB HiMAT, edited by P. Anreiter, G. Goldenberg, K. Hanke, R. Krause, W. Leitner, F. Mathis, K. Nicolussi, K. Oeggl, E. Pernicka, M. Prast, J. Schibler, I. Schneider, H. Stadler, T. Stöllner, G. Tomedi and P. Tropper, pp. 335-338. Innsbruck, Austria.

Gavira, M.C. 2005. Producción de plata en el mineral de San Agustín de Huantajaya (Chile) 1750-1804). Chungara Revista de Antropología Chilena 37:37-57.

Gil Montero, R. Tecnología minera en los siglos XVI-XIX: una perspectiva comparada. In Cultura, Sociedad y Democracia en América Latina, edited by K. Bodemer. Editorial Iberoamericana, Alemania (en prensa).

Godoy, R. 1985. Mining: Anthropological perspectives. Annual Review of Anthropology 14:199-217.

González, C. and C. Westfall 2008. Atacameños en El Salvador: Nuevas apreciaciones sobre un fardo funerario del Cementerio Las Turquesas. Estudios Atacameños 35:49-73.

Grattan, J., S. Huxley, L. Abu Karaki, H. Toland, D. Gilbertson, B. Pyatt and Z. Al-Saad 2002. 'Death... more desirable than life'? The human skeletal record and toxicological implications of ancient copper mining and smelting in Wadi Faynan, southwestern Jordan. Toxicology and Industrial Health 18:297-307.

Grattan, J., L. Abu Karaki, D. Hine, H. Toland, D. Gilbertson, Z. Al-Saad and B. Pyatt 2005. Analyses of patterns of copper and lead mineralization in human skeletons excavated from an ancient mining and smelting centre in the Jordanian desert: a reconnaissance study. Mineralogical Magazine 69:653-666.

Hidalgo, J. and M. Castillo 2004. Antonio de O'Brien y la explicación de los minerales de Huantajaya, sus nombres y beneficio (1765). Llull 27:61-93.

Iribarren, J. 1972-1973. Una mina de explotación incaica: El Salvador-provincia de Atacama. Actas del VI Congreso de Arqueología Chilena, pp. 267-283. Editorial Universitaria, Santiago.

Kuzmanic, I. and J. Sanhueza 1984. Un enterratorio procedente del mineral de El Salvador, III Región. Estudios Atacameños 7:278-295.

Latcham, R. 1938. Arqueología de la Región Atacameña. Prensas de la Universidad de Chile, Santiago.

Lechtman, H. y A. Macfarlane 2005. Metalurgia del bronce en los Andes Sur Centrales: Tiwanaku y San Pedro de Atacama. Estudios Atacameños 30:7-27.

Lecoq, P. 1987. Caravanes de lamas, sel et échanges dans une communauté de Potosí, en Bolivie. Bulletin de l'Institut Français d'Etudes Andines 16 (3-4):1-38.

Léjeal, L. 1904. L'Exposition de la Mission française de l'Amérique du Sud au Trocadéro. Journal de la Société des Américanistes 3:321-328.

Le Paige, G. 1972-1973. Tres cementerios indígenas en San Pedro de Atacama y Toconao. Actas del VI Congreso Nacional de Arqueología Chilena, pp. 163-187. Editorial Universitaria, Santiago.

Llagostera, A. 2004. Los Antiguos Habitantes del Salar de Atacama, Prehistoria Atacameña, Universidad Católica del Norte, Editorial Pehuén, Antofagasta. 
Llanos G. de 1983 [1609]. Diccionario y Maneras de Hablar que se usan en las Minas y sus Labores en los Ingenios y Beneficios de los Metales (con un estudio de G. Mendoza L. y un comentario de Th. Saignes). MUSEF, La Paz.

Lynch, T. and L. Núñez 1994. Nuevas evidencias incas entre Collahuasi y Río Frío (I y II Regiones del norte de Chile). Estudios Atacameños 11:145-164.

McCormac, F.G., A.G. Hogg, P.G. Blackwell, C.E. Buck, T.F. Higham and P.J. Reimer 2004. SHCAL04 Southern Hemisphere Calibration, 0-11 Cal Kyr BP. Radiocarbon 46:1087-1092.

Maldonado, B., T. Rehren, E. Pernicka, L. Núñez and A. Liebbrandt 2010. Early copper metallurgy in Northern Chile. In Metalla, Archäometry un Denkmalpflege 2010, edited by O. Hahn, A. Hauptmann, D. Modarressi-Tehrani and M. Prange, pp. 96-98. Jahrestagung im Deutschen Bergbau-Museum, Bochum.

Mead, C.W. 1921. Prehistoric mining in western South America. Natural History 5:453-456.

Medina, J.T. 1901. La momia de Chuquicamata. La Revista Nueva 4:144-154.

- - - 1919. La Momia de Chuquicamata. Imprenta y encuadernacion "El Globo", Santiago.

Mendoza, G. 1983. Terminología y tecnología minera en el área andina de Charcas: García de Llanos, un precursor (1598-1611). In Diccionario y Maneras de Hablar que se Usan en las Minas y sus Labores en los Ingenios y Beneficios de los Metales, Llanos, G. de. 1983 [1609], pp. VII-LXXI, MUSEF, La Paz.

Money, M. 2004. Oro y Plata en los Andes. Significados en los Diccionarios Aymara y Quechua. Siglos XVI-XVII. CIMA Editores, La Paz.

Munizaga, J., M.J. Allison, E. Gerszten and D.M. Klurfeld 1975. Pneumoconiosis in Chilean miners from the 16th Century. Bulletin of the New York Academy of Medicine 51(11):1281-1293.

Nash, J. 1979. We Eat the Mines and the Mines Eat Us: Dependency and Exploitation in Bolivian Tin Mining Communities. Columbia University Press, Nueva York.

Núñez, L. 1987. Tráfico de metales en el área centro-sur andina: factos y expectativas. Cuadernos del Instituto Nacional de Antropología 12:73-107.

- - - 1999. Valoración minero-metalúrgica circumpuneña: menas y mineros para el Inka rey. Estudios Atacameños 18:177-222.

- - - 2006. La orientación minero-metalúrgica de la producción atacameña y sus relaciones fronterizas. In Esferas de Interacción Prehistóricas y Fronteras Nacionales Modernas: Los Andes Surcentrales, edited by H. Lechtman, pp. 205-260. IEP-IAR, Lima.

- - - 2012. La minería prehistórica del desierto de Atacama (norte de Chile). In Tesoros de los Andes. El cobre chileno para el mundo, edited by R. Slotta and I. Schnepel, pp.213-224. Bochum, Germany.

Núñez L., C. Agüero, B. Cases and P. de Souza 2003. El campamento minero Chuquicamata-2 y la explotación cuprífera prehispánica en el desierto de Atacama. Estudios Atacameños 25:7-34.

Núñez, L. and T. Dillehay 1995 [1979]. Movilidad Giratoria, Armonía Social y Desarrollo en los Andes Meridionales: Patrones de Tráfico e Interacción Económica. (Ensayo). Universidad Católica del Norte, Antofagasta.

Núñez, L., M. Grosjean and I. Cartajena 2005. The expansion of the Inka empire into the Atacama Desert. In $23^{\circ} \mathrm{S}$ : Archaeology and Environmental History of the Southern Deserts, edited by M. Smith and P. Hesse, pp. 324-332. National Museum of Australia Press, Canberra.

Petersen, G. 2010. Mining and Metallurgy in Ancient Perú. Geological Society of America, Boulder, Colorado, USA.

Philippi, R. 1860. Viage al Desierto de Atacama (hecho de orden del gobierno de Chile en el verano de 1853-54). Librería de Eduardo Antón, Santiago.

Philippi, F. 1901. La momia de Chuquicamata. Diversas teorías y opiniones. El Mercurio, Año 1, Nf. 322 (Santiago, jueves 18 de abril de 1901).

Pickin, J. 1990. Stone Tools and Early Metal Minning in England and Wales. In Early mining in the British Isles, edited by P. Crew and S. Crew, pp. 39-42. Plas Tan y Bwlch Snowdonia National Park Study Center, London.

Platt, T., Bouysse-Cassagne and O.Harris 2006. Qaraqara-Charka. Mallku, Inka y Rey en la Provincia de Charcas (Siglos XV-XVII). Historia Antropológica de una Confederación Aymara. IFEA, Plural, University of St. Andrews, University of London, Inter American Foundation and FCBCB, La Paz.

Rees, Ch. 1999. Elaboración, distribución y consumo de cuentas de malaquita y crisocola durante el período Formativo en la vega de Turi y sus inmediaciones, subregión del río Salado, norte de Chile. In Los Tres Reinos: Prácticas de Recolección en el Cono Sur de América, edited by C. Aschero, A. Korstanje and P. Vuoto, pp. 85-98. Instituto de Arqueología y Museo, Universidad Nacional de Tucumán, Tucumán.

Salazar-Soler, C. 2002. Anthropologie des Mineurs des Andes. Dans les Entrailles de la Terre. L'Harmattan, Paris.

Salazar, D. 2002. El Complejo Minero San José del Abra, II Región (1450-1536 d.C.) Una Aproximación a la Arqueología de la Minería. Master's Thesis, Faculty of Social Sciences, Universidad de Chile.

- - - 2003-2004. Arqueología de la minería: propuesta de un marco teórico. Revista Chilena de Antropología 17:125-150.

- - - 2008. La organización de la producción minera en San José del Abra durante el Período Tardío. Estudios Atacameños 36:43-72.

Salazar, D., H. Salinas and P. Corrales 2007. El pirquén olvidado: reflexiones arqueológicas a partir de faenas pirquineras en el norte de Chile. In Signos en el Tiempo y Rastros en la Tierra, Actas de las V Jornadas de Arqueología e Historia de las Regiones Pampeana y Patagónica, Vol. II, pp. 45-52. Universidad Nacional de Luján, Luján.

Salazar, D. and H. Salinas 2008. Tradición y transformaciones en la organización de los sistemas de producción mineros en el norte de Chile prehispánico: San José del Abra, siglos I al XVI DC. In Minas y Metalurgia en los Andes Centrales y del Sur. Desde Tiempos Prehispánicos hasta el Siglo XVII, edited by P. Cruz, P. Absi and M. Van Buren, pp. 163-200. University of Colorado State, Sucre. 
Salazar, D, H. Salinas, V. Mcrostie, R. Labarca and G. Vega 2010. Cerro Turquesa: Diez siglos de producción minera en el extremo norte de Chile. Actas del XVII Congreso Nacional de Arqueología, Tomo 2, pp. 1085-1097. Ediciones Kultrún, Valdivia.

Salazar, D., V. Figueroa, B. Mille, G. Manríquez and P. Casanova 2010. La producción de metales en las sociedades costeras del norte grande de Chile. Actas del XVII Congreso Nacional de Arqueología Argentina, Mendoza.

Salazar, D., V. Castro, J. Michelow, H. Salinas, V. Figueroa and B. Mille 2010. Minería y metalurgia en la costa de la región de Antofagasta, extremo norte de Chile. Boletín del Museo Chileno de Arte Precolombino 15:9-23.

Salazar, D., D. Jackson, J.L. Guendon, H. Salinas, D. Morata, V. Figueroa, G. Manríquez and V. Castro 2011. Early Evidence (ca. 12,000 B.P.) for Iron Oxide Mining in the Pacific Coast of South America. Current Anthropology 52:463-475.

Salazar D., V. Figueroa, D. Morata, B. Mille, G. Manriquez and A. Cifuentes 2011. Metalurgia en San Pedro de Atacama durante el Período Medio: Nuevos datos, nuevas preguntas. Revista Chilena de Antropología 13:123-148.

Salinas, H. 2007. Estudios acerca de la Organización de la Tecnología Minera Prehispánica en el Loa Superior, Norte de Chile. Memoria para optar al Título de Arqueólogo. Departamento de Antropología, Facultad de Ciencias Sociales, Universidad de Chile.

Salinas, H. and D. Salazar 2008. Cadenas operativas y sistemas de explotación minera prehispánica. In Puentes hacia el Pasado: Reflexiones Teóricas en Arqueología, edited by D. Jackson, D. Salazar and A. Troncoso, pp. 73-91. Serie Monográfica de la Sociedad Chilena de Arqueología 1, Santiago.

Salinas, H., D. Salazar, D. Órdenes and J. Parra 2010. Organización tecnológica y sistemas de explotación minera prehispánica. Actas del XVII Congreso Nacional de Arqueología, Tomo 2, pp. 10991109. Ediciones Kultrún, Valdivia.

Sancho de la Hoz, P. 1938 [1534]. Relación para S.M. de lo sucedido en la conquista y pacificación de estas provincias de la Nueva Castilla y de la calidad de la tierra, después que el Capitán Hernando Pizarro se partió y llevó a su Majestad la relación de la victoria de Caxamarca y de la prisión del cacique Atabalipa. In Los Cronistas de la Conquista, editado por H. Arteaga. Biblioteca de la Cultura Peruana. Desclée de Brouwer, Paris.

Sarikaya, S., S. Özdolap, A.G. Mungan, S. Gümüstas, Ü. Koç, B. Güven and F. Begendik 2006. Effect of underground working on vitamin $\mathrm{D}$ levels and bone mineral densities in coal miners: a controlled study. The Journal of International Medical Research 34:362-366.

Sarikaya, S., S. Özdolap, S. Gümüstas and Ü. Koç 2007. Low back pain and lumbar angles in Turkish coal miners. American Journal of Industrial Medicine 50:92-96.
Sepúlveda, M. and E. Laval 2010. Uso de minerales de cobre en la pintura rupestre de la localidad de río Salado (II Región, norte de Chile). Actas del XVII Congreso Nacional de Arqueología, Tomo 2, pp. 1111-1122. Ediciones Kultrún, Valdivia.

Shepherd, R. 1980. Prehistoric Mining and Allied Industries. Academic Press INC Ltda, London.

Shimada, I. 1994. Pre-Hispanic metallurgy and mining in the Andes: recent advances and future tasks. In Quest of Mineral Wealth: Aboriginal and Colonial Mining and Metallurgy in Spanish America, edited by A. Craig and R. West, pp. 135-152, Geoscience and Man Vol. 33, Louisiana.

Soto, C. 2010. Tipología de cuentas de collar en la Quebrada de Tulán (Salar de Atacama): Nueva línea de evidencia para la transición Arcaico-Formativo. Actas del XVII Congreso Nacional de Arqueología Chilena, tomo II, pp. 1123-1134. Valdivia.

Stoellner, T. 2011. Präkolumbischer Bergbau in den Anden. In Schätze der Anden, Chile kupfer für die welt, edited by R. Slotta and I. Schnepel, pp. 181-212. Bochum, Germany.

Sullivan, L.R. 1921. The physical characteristics of the two prehistoric Chilean miners. Natural History 5:456-457.

Sutulov, A. 1975. Antecedentes históricos de la producción de cobre en Chile. In El Cobre Chileno, edited by A. Zauschquevich and A. Sutulov, pp. 1-115. Editorial Universitaria, Santiago.

Thornburn, J. 1990. Stone Mining Tools and the Field for Early Mining in Mid-Wales. In Early Mining in the British Isles, edited by P. Crew and S. Crew, pp. 43-48. Plas Tan y Bwlch Snowdonia National Park Study Center, London.

Timberlake, S. 1990. Excavations at Parys Mountain and Nantyreira. In Early Mining in the British Isles, edited by P. Crew and S. Crew, pp.15-21. Plas Tan y Bwlch Snowdonia National Park Study Center, London.

Varón, R. 1978. Minería colonial peruana: un ejemplo de integración al sistema económico mundial, siglos XVI-XVIII. Historia y Cultura 11:143-170.

Van der Merwe A.E., M. Steyn and E.N. Labbe 2010. Trauma and Amputations in $19^{\text {th }}$ Century Miners from Kimberley, South Africa. International Journal of Osteoarchaeology 20:291-306.

Vetter, L. 2008. Plateros Indígenas en el Virreinato del Perú: Siglos XVI y XVII. Fondo Editorial UNMSM. Lima.

Westfall, C. and C. González 2010. Mina Las Turquesas: un asentamiento minero lapidario preincaico en el extremo meridional circumpuneno Región de Atacama, Chile. Actas del XVII Congreso Nacional de Arqueología, Tomo 2, pp. 1073-1084. Ediciones Kultrún, Valdivia.

Weisgerber, G. 2006. Chuquicamata und anderer indianischer Bergbau vor Kolumbus. Der Anschnitt 58 (1-2):2-17. 


\section{Notes}

1 The Mining set is one among various markers which define discrete activity areas in the spatial organization of mining activity. According to Salinas and Salazar (2008), the identification of activity areas, the understanding of artefact functionality and the reconstruction of extractive techniques employed by miners are the main three components of mining technology and technical processes, which in turn is one of the four key variables of prehistoric mining productive systems (see also Salazar 2003-2004; Salazar and Salinas 2008).

2 "The workers work with candles, dividing up the work so that some work during the day while others rest, and viceversa. The metal is usually hard, and they extract it by blows from an iron rod, breaking it like stoneworkers. Afterwards, hunched over, they mount a crude ladder made of three strands of leather twisted like a thick rope, with wooden boards suspended between them as steps, so that one man can climb up as another climbs down. These ladders are ten estados long, and at the end of them is another ladder of the same length that begins at a ledge or support, where wooden platforms have been built to allow them to rest, as there are many ladders to climb. Each man carries a load of two arrobas of metal in a sac tied onto his back by straps that cross his chest; they go up the ladder three at a time. The one in front carries a candle attached to his index finger, to light the way" [translated by the authors].

3 "Comba se dice de cumpa, que en la general quiere decir martillo grande, y a los que los indios daban este nombre y de que usaban para este ministerio en sus labores eran piedras muy redondas como bolas de todos los tamaños, $y$ así en las labores antiguas de Oruro y de otros minerales se hallan muchas de aquel tiempo, (...), y aquí se dice combear lo que se trabaja con este instrumento, que es lo mismo que golpear" (García de Llanos 1983 [1609]:54).

4 According to Bird (1979: 113-114), the complete inventory of objects, including those of 1912 and 1914, is as follows:

- 17 hafted stone hammers (whole and broken)

- six hafted-type stone hammer heads lacking handles

- four similar stone hammers used without handles

- seven thin hammer stones used without handles

- nine wooden tools with blunt ends

- four shovels (two wooden blades and intact handles)

- one stone blade with broken handle and one wooden blade only.
5 Quoting a personal communication by Mead and making reference to the ethnographical classifications of his time, Sullivan (1921:457) even suggests that the mummies donated by Morgan and the Guggenheim brothers would be 'Araucanos': "As nearly as we can reconstruct their physical appearance from the remains, there is every reason to believe that Mr. Mead is correct in saying that the mummies were probably Araucanians".

6 Chervin and Boman thought of a woman because of the mummy' braids.

7 The mummy entered the collections of the Musée d'Ethnographie du Trocadéro in 1902, under catalogue number 71.1902.31.7. We have consulted the archives of different museums associated with the French Scientific Mission (Musée d'Ethnographie du Trocadéro, Musée de l'Homme, Musée du quai Branly, Muséum national d'Histoire naturelle, Muséum d'Histoire naturelle de Toulouse, Musée d'Anthropologie préhistorique de Monaco, Musée d'Archéologie Nationale (Saint-Germain-en-Laye), Museum of World Culture (Göteborg)) but had no success in locating it.

8 The current inventory numbers of the objects associated with the miner mummy are as follows: capacho (71.1902.31.1), basket (71.1902.31.2), hammer and haft (71.1902.31.3.12), hammer (71.1902.31.4), hammer (?) (71.1902.31.5), hammer (?) (71.1902.31.6), of which the only object not located is the capacho.

9 Word commonly used in the Atacama region to refer to small mine shafts.

10 The hammer of which Boman published a photograph (Boman, 1908, Figure 110) has been quoted and confused in literature with the hammer of Copper Man (Bray 1971).

1123 mining stemmed hammers and four lithic shovels from Salinas Grandes in Jujuy, Argentina were collected by the French Scientific Mission (Boman 1908; Léjéal 1904). These objects are currently housed at the Musée du Quai Branly (Paris). Boman takes a particular interest in these objects, mentioning also the presence of several hafted axes, such as those studied by Gustav Nordenskjöld in Colorado (USA), and others from the MET Collection from the Zuñis (Boman, 1908:564). 
